\title{
Potential of Fermented Sausage-Associated Lactic Acid Bacteria to Degrade Biogenic Amines During Storage
}

\author{
Jirasak Kongkiattikajorn
}

Additional information is available at the end of the chapter

http://dx.doi.org/10.5772/51302

\section{Introduction}

Biogenic amines (BAs) are organic bases with aliphatic, aromatic or heterocyclic structures that can be found in several foods, in which they are mainly produced by microbial decarboxylation of amino acids, with the exception of physiological polyamines. BAs may be of endogenous origin at low concentrations in non-fermented food such as fruits, vegetables, meat, milk and fish. High concentrations have been found in fermented foods as a result of a contaminating microflora exhibiting amino acid decarboxylase activity (SillaSantos, 1996). However, BAs can also trigger human health problems leading to palpitations, hypertension, vomiting, headaches and flushing if food containing high concentrations are ingested. In fermented foods, some lactic acid bacteria (LAB) are able to convert available amino acid precursors into BAs via decarboxylase or deiminase activities during or following ripening processes. For this reason, amino acid catabolism by LAB can affect both the quality and safety of fermented foods (Verges et al., 1999). The amount and type of BAs formed depends on the nature of food and particularly on the kind of microorganisms present. Enterobacteriaceae and certain LAB are particularly active in the production of BA (Beutling, 1996). These amine-producing microorganisms either may form part of the food associated population or may be introduced by contamination before, during or after processing of the food product. Therefore, microorganisms naturally present in raw materials, introduced throughout the processing or added as starter culture can critically influence BA production during the manufacture of fermented products (BoverCid et al., 2000).

Nham is a Thai-style fermented pork sausage. Nham ripening generally takes 3-5 days and relies mainly on adventitious microorganisms, which are normally found in raw materials. 
$\mathrm{LAB}$ produce organic acids from carbohydrates and cause the $\mathrm{pH}$ drop, which contribute to Nham formation. Micrococcus and Staphylococcus are capable of reducing nitrate to nitrite, which is important in producing the characteristic pigmentation. Also, as a source of lipolytic and proteolytic enzymes, they may contribute to flavor production. Therefore, the acidification and the proteolytic process occurring during Nham ripening make the environment particularly favorable for BAs production.

During meat ripening, microbial growth, acidification and proteolysis provide favourable conditions for BA production. The species of lactobacilli most commonly found in meat and meat products are Lactobacillus sake and Lactobacillus curvatus, which together with Lactobacillus bavaricus and Lactobacillus plantarum constitute the main microbial flora isolated from fermented sausages. Other bacteria that can be found in relatively high numbers include enterococci (E. faecalis and E. faecium), which also contribute to the ripening process. However, the presence of enterococci might also reflect a given level of contamination or a poor curing process. Salt-tolerant, nitrate-reducing coagulase-negative staphylococci are also detected in relatively high numbers in ripened meat products. Staphylococcus xylosus is the main species found in Spanish fermented sausages, although S. carnosus can also be used as a starter culture. BAs can be degraded through oxidative deamination catalyzed by amines oxidase $(\mathrm{AO})$ with the production of aldehyde, ammonia and hydrogen peroxide. Monoamine oxidases (MAOs) and diamine oxidases (DAOs) had been described from some genus of the family Enterobacteriaceae (Yamashita et al., 1993). The potential role of microorganisms with $\mathrm{AO}$ activity had become a particular interest in the last few years to prevent or reduce BA accumulation in food products, especially fermented foods. Mah and Hwang (2009) investigated the effect of Staphylococcus xylosus to inhibit BA formation in a salted and fermented anchovy. Reduction of tyramine during ripening of fermented sausages was achieved when Micrococcus varians was applied as starter culture (Leuschner and Hammes, 1998). Inoculation of L. plantarum in sauerkraut effectively suppressed the production of tyramine, putrescine and cadaverine (Kalac et al., 2000).

BAs are physiologically inactivated by $\mathrm{AO}$, which are enzymes found in bacteria, fungi, plant and animal cells able to catalyse the oxidative deamination of amines with production of aldehydes, hydrogen peroxide and ammonia (Cooper, 1997). The sequential action (in the presence of an electron acceptor, such as $\mathrm{O}_{2}$ ) of an $\mathrm{AO}$ and an aldehyde dehydrogenase leads to the production of an acid and ammonia, which can be used to support microbial growth (Parrot et al., 1987). MAO and DAO activity has been described in higher organisms as well as in bacteria (Murooka et al., 1976, 1979; Ishizuka et al., 1993). There are relevant differences between microbial $\mathrm{AO}$ in terms of substrate specificity and location, as stated by Cooper (1997). DAOs can oxidase several BA, such as putrescine and histamine, and their activity can be affected by substrate inhibition; aminoguanidine, antihistaminic drugs and foodborne inhibitors, such as ethanol, carnosine, thiamine, cadaverine and tyramine, reduce their activity (Lehane and Olley, 2000). The potential role of microorganisms involved in food ripenings with $\mathrm{AO}$ activity has been investigated with the aim to prevent or reduce the accumulation of BA in foods. Leuschner et al. (1998) tested in vitro the potential amine degradation by many bacteria isolated from foods and, in particular, in strains belonging to the genera Lactobacillus, 
Pediococcus, Micrococcus, as well as to the species S. carnosus and Brevibacterium linens. They found that this enzymatic activity can be present at very different quantitative levels. Tyramine oxidase activity of several microbial strains was strictly dependent on $\mathrm{pH}$ (with an optimum at 7.0), temperature and $\mathrm{NaCl}$, as well as glucose and hydralazine concentration. Moreover, this enzyme was characterised by a higher potential activity under aerobic conditions. Temperature has also an important effect on histamine degradation (Dapkevicius et al., 2000). The highest degradation rate of this amine was observed at $37^{\circ} \mathrm{C}$, but at $22^{\circ} \mathrm{C}$ and $15{ }^{\circ} \mathrm{C}$, degradation was still considerable. The $\mathrm{AO}$ responsible for this degradation has its optimum temperature at $37^{\circ} \mathrm{C}$ and retains about $50 \%$ of its maximum activity at $20{ }^{\circ} \mathrm{C}$ (Schomburg and Stephan, 1993). Many S. xylosus strains isolated from artisanal fermented sausages in southern Italy showed the ability to degrade BA in vitro (Martuscelli et al., 2000). Among the strains tested, S. xylosus S81 completely oxidised histamine, but it degraded, under the adopted conditions, also a part of tyramine. Even if the AO activity in vitro of microorganisms is not quantitatively reproducible in vivo (due to the more severe conditions and, in particular, to the low $\mathrm{O}_{2}$ tension, $\mathrm{pH}$ and salt concentration), reduction of histamine in dry sausages has been observed in the presence of AO-positive staphylococcal starter cultures (Leuschner and Hammes, 1998). In addition, important reduction of the concentration of tyramine and putrescine in the presence of AO positive $S$. xylosus starter cultures have been observed by Gardini et al. (2002). In other words, BA presence in foods is the consequence of a complex equilibrium between the composition of the food and the enzymatic activities of the microbial population. Together with the decarboxylating aptitude of the starter cultures, the presence and relative activity of $\mathrm{AO}$ should be considered as an important characteristic in the selection of starter cultures used in the production of fermented foods.

Since Nham is normally consumed without cooking, proper acid production is important to determine the quality and safety of Nham for consumption. Depending on the initial number of contamination, the occurrence of pathogens such as Salmonella spp., Staphylococcus aureus, and Listeria monocytogenes was found specially in Nham with $\mathrm{pH}$ higher than 4.6. Due to inconsistency of product quality and ambiguous product safety, improved process of Nham ripening has been developed by using a starter culture technology. Starter cultures are applied to improve and stabilize the quality of the final product and to shorten the ripening period of Nham production. Meanwhile, only little information is available on the effect of starter culture on BA reduction in Nham. Therefore, the objective of this study was to investigate the effectiveness of AOs activity of LAB in inhibiting BA accumulation during Nham ripening. In addition, the change of chemical and microbial properties of Nham during ripening and subsequently during 28 days stored at different temperature was investigated.

\section{Materials and methods}

\subsection{Microbiological analysis}

Nham sausages ( $25 \mathrm{~g}$ ) were aseptically transferred into a stomacher bag, with $225 \mathrm{~mL}$ of peptone $(0.85 \%$ of sodium chloride added) and then homogenized for two minutes. Further decimal dilutions were made and then $100 \mu \mathrm{L}$ of each dilution was spread onto agar plates. 
Aerobic plate count agar was used to determine total aerobic. BA producing bacteria were counted using differential media supplemented with amino acids as precursor of BAs (Joosten and Northolt, 1989). The media contained of tryptone $(0.5 \%)$, yeast extract $(0.5 \%)$, sodium chloride $(0.5 \%)$, glucose $(0.1 \%)$, Tween $80(0.05 \%), \mathrm{MgSO}_{4} \bullet 7 \mathrm{H}_{2} \mathrm{O}(0.02 \%), \mathrm{CaCO}_{3}$ $(0.01 \%), \mathrm{MnSO}_{4} \bullet 4 \mathrm{H}_{2} \mathrm{O}(0.005 \%), \mathrm{FeSO}_{4} \bullet 7 \mathrm{H}_{2} \mathrm{O}(0.004 \%)$, bromocresol purple $(0.006 \%)$, amino acid $(2 \%)$ and agar $(2 \%)$. The medium contained the precursor amino acids $(0.5 \%$ tyrosine di-sodium salt and $0.25 \%$ L-histidine monohydrochoride, L-ornithine monohydrochoride, Llysine monohydrochoride, L- phenylalanine, and L-tryptophan), pyridoxal-5-phosphate as a codecarboxylase factor, growing factors and buffer compounds. All plates were then incubated for $48 \mathrm{~h}$ at $37^{\circ} \mathrm{C}$. Bacterial colonies which developed on each agar were then enumerated and expressed as log colony forming unit (CFU)/mL. Only bacterial colonies with purple halo in the differential media were counted as BAs producing bacteria.

\subsection{Bacterial strains and growth conditions}

Bacterial strains isolated from different fermented sausages were tested. LAB were grown in MRS broth.

\subsection{Determination of amine degradation}

An overnight culture was harvested, washed with $0.05 \mathrm{M}$ phosphate buffer $(\mathrm{pH} 7)$ and the cell pellet resuspended in $0.05 \mathrm{M}$ phosphate buffer supplemented with tyramine, histamine, tryptamine, phenylethylamine, putrescine, and cadaverine. The cell concentration was adjusted to $10^{6}, 10^{7}$ and $10^{8} \mathrm{CFU} / \mathrm{mL}$. The cell suspensions $(20 \mathrm{~mL})$ were incubated in a 100 $\mathrm{ml}$ flask and shaken at $200 \mathrm{rpm}$. Samples were taken and added to an equal amount of $1 \mathrm{M}$ $\mathrm{HCl}$. The mixture was boiled for $10 \mathrm{~min}$ and centrifugated at $9000 \mathrm{~g}$. The supernatant was frozen at $-15^{\circ} \mathrm{C}$ until HPLC analysis.

\subsection{Preparation of starter culture}

Starter cultures used in this study were L. plantarum + L. sake, which were isolated from sausage. A loop from a slant tryptic soy agar culture of each culture was inoculated in $10 \mathrm{~mL}$ of tryptic soy broth and incubated at $37^{\circ} \mathrm{C}$ for $24 \mathrm{~h}$. Five milliliters of the culture was then transferred to $100 \mathrm{~mL}$ of tryptic soy broth and incubated at $37^{\circ} \mathrm{C}$ for another $24 \mathrm{~h}$. The culture was centrifuged at 10,000 $\mathrm{g}$ for $10 \mathrm{~min}$ at $4^{\circ} \mathrm{C}$ and then washed with broth. Broth was prepared by homogenizing 1 part with 9 part of distilled water, filtered, adjusted to $\mathrm{pH}$ 7.0 and then autoclaved at $121^{\circ} \mathrm{C}$ for $15 \mathrm{~min}$. After centrifugation, the cell pellet was resuspended in sterile fish broth, adjusted to approximately $10^{7}$ cell/g and used as starter culture in sauce ripening.

\subsection{Nham preparation}

Minced pork (56\%), pieced cooked pork skin (37\%), garlic (3.2\%), cooked rice $(2 \%)$, sodium polyphosphate $(0.15 \%)$, sodium chloride $(1.5 \%)$ and sodium erythrobate $(0.15 \%)$ chili $(1 \%)$ 
were mixed thoroughly, packed into a plastic casing and sealed before incubation. Two separated batches of fermented sausage were prepared without starter culture and with different starter cultures (L. plantarum + L. sake) of approximately $10^{7} \mathrm{cell} / \mathrm{g}$. After incubation the fermented sausages were homogenized for analysis.

\subsection{Physical and chemical analyses}

The $\mathrm{pH}$ was measured directly from samples using a microcomputerized $\mathrm{pH}$ meter, inserting the electrode into the middle of the sausage. Moisture was determined by drying the sample at $100-105^{\circ} \mathrm{C}$ until a constant weight was achieved. The color of Nham was determined by Minolta Model DP-301 colorimeter. Color values (L, a, and b) were measured. A white standard tile was used to calibrate the colorimeter $(L=100.01, a=-0.01, b=$ -0.02 ) before measurements. Therefore $\mathrm{L}$ measures lightness (luminosity) and varies from white to black. The chromatically ( $a$ and $b$ values) gives designations of color as follows; $a-$ value measures redness when positive, gray when zero, and greenness when negative, bvalue measures yellowness when positive, gray when zero, and blueness when negative. The titratable acidity (TA) determined as total acid was estimated according to AOAC (2000) and expressed as $\mathrm{g} / 100 \mathrm{~g}$ dry matter. TCA (trichloroacetic acid)-soluble peptide of the fermented sausages was measured by the method of Greene and Babbitt (1990). The oligopeptide content in the supernatant was determined according to by the method of Lowry et al (1951). Results were expressed as $\mu \mathrm{mol} / \mathrm{g}$ (dry matter). Free $\alpha$-amino acid was measured using TNBS according to Benjakul and Morrissey (1997) Results were expressed as $\mu \mathrm{mol} / \mathrm{g}$ (dry matter).

\subsection{Extraction of amino acids and BAs}

$10 \mathrm{ML}$ of $10 \%(\mathrm{w} / \mathrm{v})$ trichloroacetic acid (TCA) were added to 3 g-samples, and homogenization of the mixture was effected via shaking for $1 \mathrm{~h}$. The extract was then filtered through Whatman No. 1 filter paper. To remove any fat, the samples were kept at $20{ }^{\circ} \mathrm{C}$ for $1 \mathrm{~d}$, and then centrifuged at $7000 \mathrm{~g}$ for $15 \mathrm{~min}$. The supernatants were collected and filtered through a $0.25 \mu \mathrm{m}$ membrane filter.

\subsection{Determination of BAs}

Amines were determined by the high-performance liquid chromatography (HPLC) method described by Hernández-Jover et al. (1996). The method is based on the formation of ion pairs between amines extracted with $0.6 \mathrm{M}$ perchloric acid from 5 to $10 \mathrm{~g}$ of sample, and octanesulphonic acid present in the mobile phase. Separation is preformed using a reversed phase column, then a postcolumn derivatization with o-phthalaldehyde (OPA) is followed by spectrofluorimetric detection. The method allows one to quantify, by an external standard procedure, 6 BAs, i.e., tyramine, histamine, tryptamine, phenylethylamine, putrescine, cadaverine. Samples for BA determination were stored at $-15^{\circ} \mathrm{C}$ until required. 


\subsection{Determination of amino acids}

Free amino acids (FAAs) in samples were determined using HPLC according to the method proposed by Rozan et al. (2000). A $20 \mu \mathrm{L}$ aliquot of amino acid standard and digested sauce samples were transferred into vials and dried under vacuum. Then $20 \mu \mathrm{L}$ of drying reagent containing methanol, water and triethylamine (ratio 2:2:1 v/v) was added. Then $20 \mu \mathrm{L}$ of derivatizing reagent containing methanol, triethylamine, water and phenylisothiocyanate (PITC) (ratio 7:1:1:1 v/v) was added. The derivatized samples were then dissolved in $100 \mathrm{~mL}$ of buffer A that was used as mobile phase for HPLC. A Purospher ${ }^{\circledR}$ STAR RP-18e, $5 \mu \mathrm{m}$ column was used with buffer A (0.1 M ammonium acetate, $\mathrm{pH} 6.5)$ and buffer B $(0.1 \mathrm{M}$ ammonium acetate containing acetonitrile and methanol, 44:46:10 v/v, $\mathrm{pH} 6.5$ ) as mobile phase set for linier gradient at the flow rate of $1 \mathrm{~mL} / \mathrm{min}$. The injected sample volume was 20 $\mu \mathrm{L}$ and monitored at $254 \mathrm{~nm}$ of wavelength.

\subsection{Statistical analysis}

Data was analysed by one-way ANOVA and differences among treatment means were determined by Duncan's new multiple-range test.

\section{Results and discussion}

The effect of starter cultures of LAB on BAs and FAAs content was examined during the ripening process of Nham sausages. Microbial counts, $\mathrm{pH}$ and proteolysis-related parameters were also studied. The occurrence of amino acid-decarboxylase activity in 7 strains of LAB isolated from Nham sausages was investigated.

\begin{tabular}{|c|c|c|c|c|c|c|}
\hline \multirow{2}{*}{ Starter culture } & \multicolumn{7}{|c|}{ Percent degradation (\%) } \\
\cline { 2 - 7 } & $\begin{array}{c}\text { Trypta- } \\
\text { mine }\end{array}$ & $\begin{array}{c}\text { Phenylet } \\
\text { hylamine }\end{array}$ & $\begin{array}{c}\text { Putre- } \\
\text { scine }\end{array}$ & $\begin{array}{c}\text { Cada- } \\
\text { verine }\end{array}$ & $\begin{array}{c}\text { Hista- } \\
\text { mine }\end{array}$ & $\begin{array}{c}\text { Tyra- } \\
\text { mine }\end{array}$ \\
\hline Lactobacillus curvatus 1271 & 0 & 0 & 0 & 0 & 0 & 0 \\
\hline Lactobacillus farciminis 1452 & 0 & 0 & 0 & 0 & 0 & 5.7 \\
\hline Lactobacillus kandleri 2439 & 0 & 0 & 0 & 3.6 & 0 & 0 \\
\hline Lactobacillus kefir 2045 & 0 & 0 & 0 & 0 & 0 & 0 \\
\hline Lactobacillus plantarum 9825 & 0 & 0 & 12.6 & 9.3 & 0 & 19.4 \\
\hline Leuconostoc mali 7412 & 0 & 0 & 0 & 0 & 0 & 0 \\
\hline Lactobacillus pentosus 7054 & 0 & 0 & 5.2 & 4.7 & 0 & 0 \\
\hline Lactobacillus reuteri 7498 & 0 & 0 & 4.8 & 0 & 0 & 0 \\
\hline Lactobacillus sake 4127 & 0 & 0 & 17.3 & 8.2 & 0 & 14.5 \\
\hline
\end{tabular}

Table 1. Strains exhibiting the potential to degrade BAs in a buffer system within $24 \mathrm{~h}$ at $30^{\circ} \mathrm{C}$

The presence of BAs in a decarboxylase synthetic broth was determined by high performance liquid chromatography with OPA derivatization. Among the 9 LAB strains tested, 5 lactobacilli (in particular, L. curvatus) were amine producers and L. plantarum and L. 
sake, were non-amine forming strains. The ability of AO exhibiting strains of LAB to degrade amine in vivo during sausage ripening was investigated.

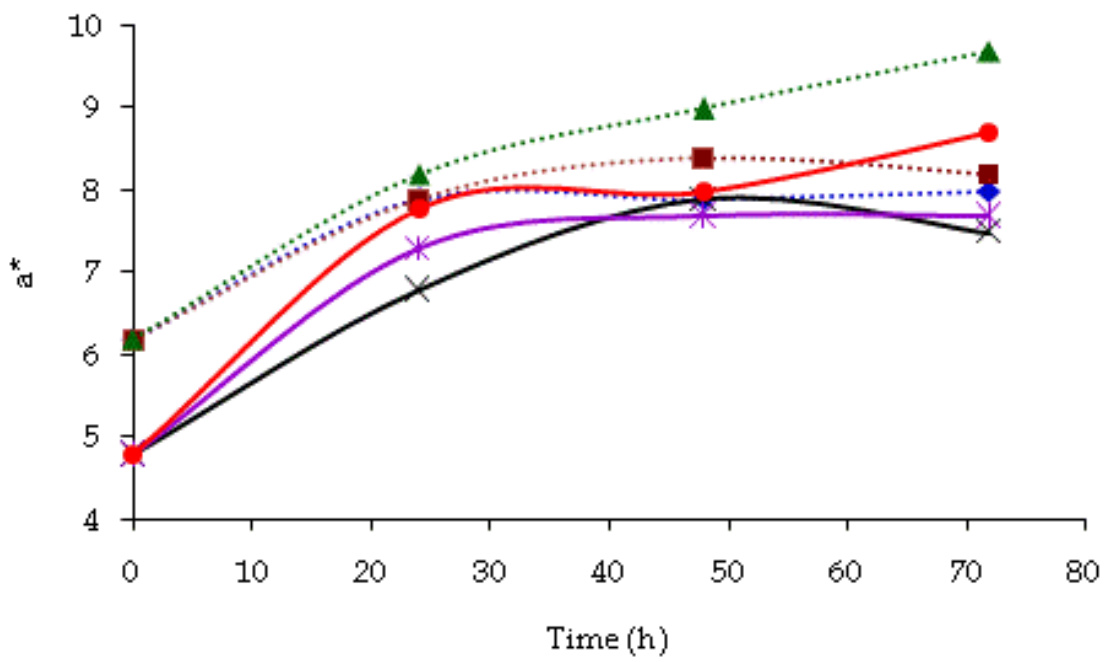

Figure 1. $\mathrm{a}^{*}$ Value during ripening of Nham control at $25^{\circ} \mathrm{C}(\bullet), 30^{\circ} \mathrm{C}(\bullet), 37^{\circ} \mathrm{C}(\Delta)$ and Nham with starters (L. plantarum + L. sake) at $25^{\circ} \mathrm{C}(\times), 30^{\circ} \mathrm{C}(*), 37^{\circ} \mathrm{C}(\bullet)$.

Fig. 1 showed $\mathrm{a}^{*}$ values represent red color of Nham during ripening time and temperature at $25^{\circ} \mathrm{C}, 30^{\circ} \mathrm{C}$ and $37^{\circ} \mathrm{C}$, respectively. The results showed a value increased according to ripening and the a value of Nham control at 72 hours $37^{\circ} \mathrm{C}$ was higher than the other sample.

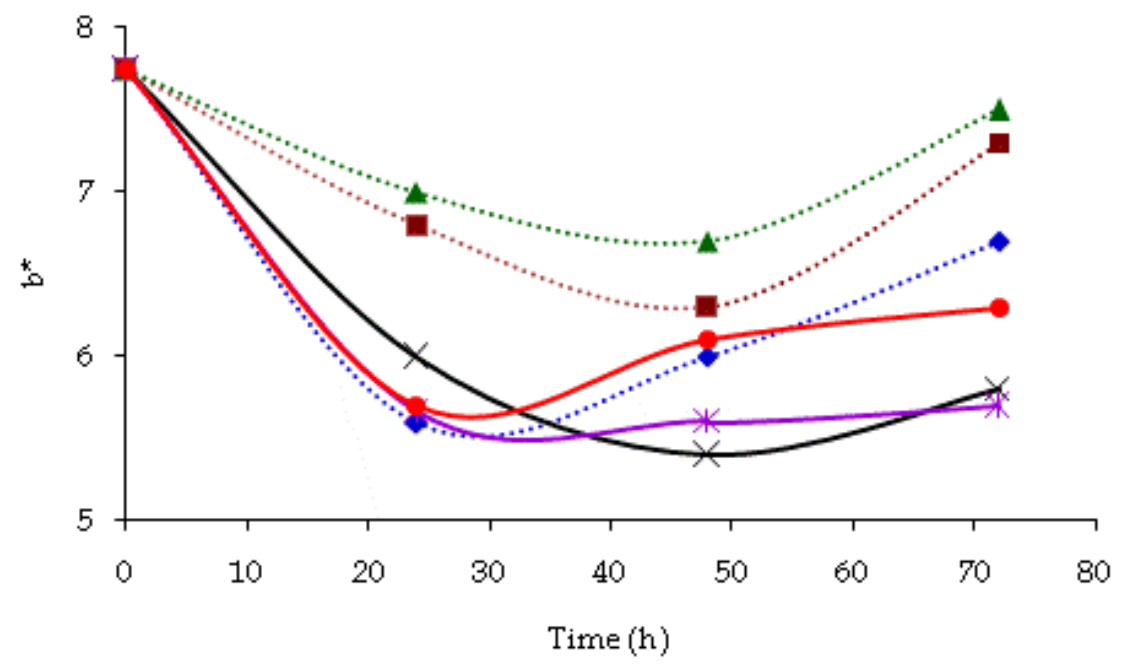

Figure 2. $\mathrm{b}^{*}$ Value during ripening of Nham control at $25^{\circ} \mathrm{C}(\bullet), 30^{\circ} \mathrm{C}(\bullet), 37^{\circ} \mathrm{C}(\boldsymbol{\Delta})$ and Nham with starters (L. plantarum + L. sake) at $25^{\circ} \mathrm{C}(\times), 30^{\circ} \mathrm{C}(*), 37^{\circ} \mathrm{C}(\bullet)$. 
Fig. 2 shows $b^{*}$ values represent yellow color of Nham during ripening time and temperature at $25^{\circ} \mathrm{C}, 30^{\circ} \mathrm{C}$ and $37^{\circ} \mathrm{C}$, respectively. The results showed $\mathrm{b}$ value decreased according to storage and the $b$ value of Nham with starters was lower than that of Nham control.

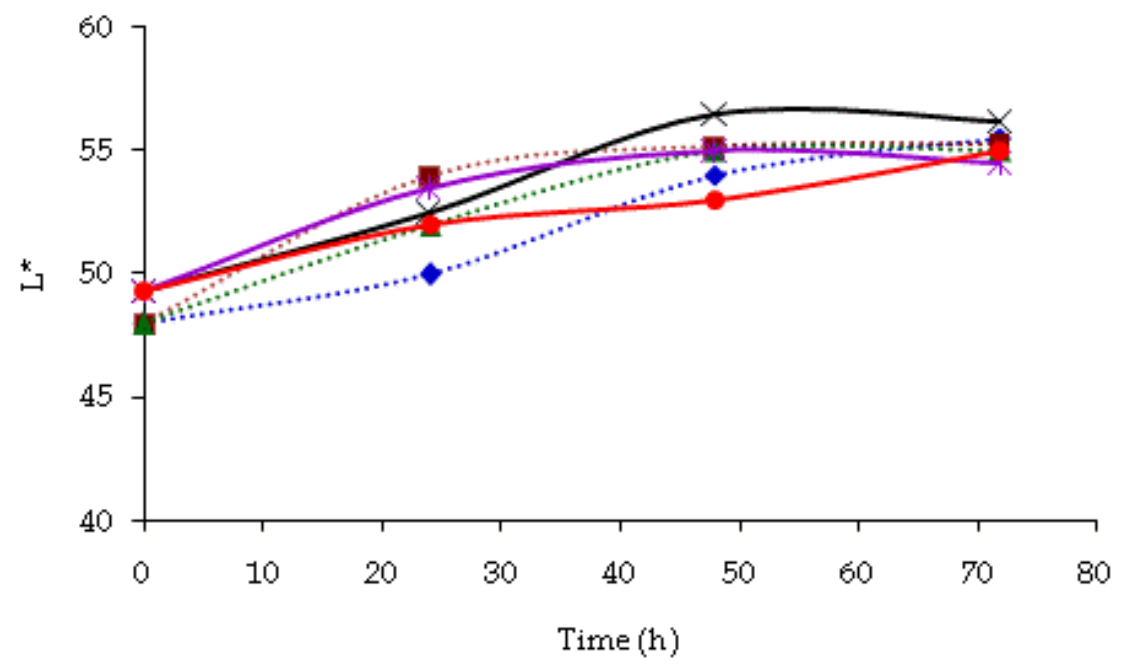

Figure 3. $\mathrm{L}^{*}$ Value during ripening of Nham control at $25^{\circ} \mathrm{C}(\bullet), 30^{\circ} \mathrm{C}(\bullet), 37^{\circ} \mathrm{C}(\boldsymbol{\Delta})$ and Nham with starters (L. plantarum + L. sake) at $25^{\circ} \mathrm{C}(\times), 30^{\circ} \mathrm{C}(*), 37^{\circ} \mathrm{C}(\bullet)$.

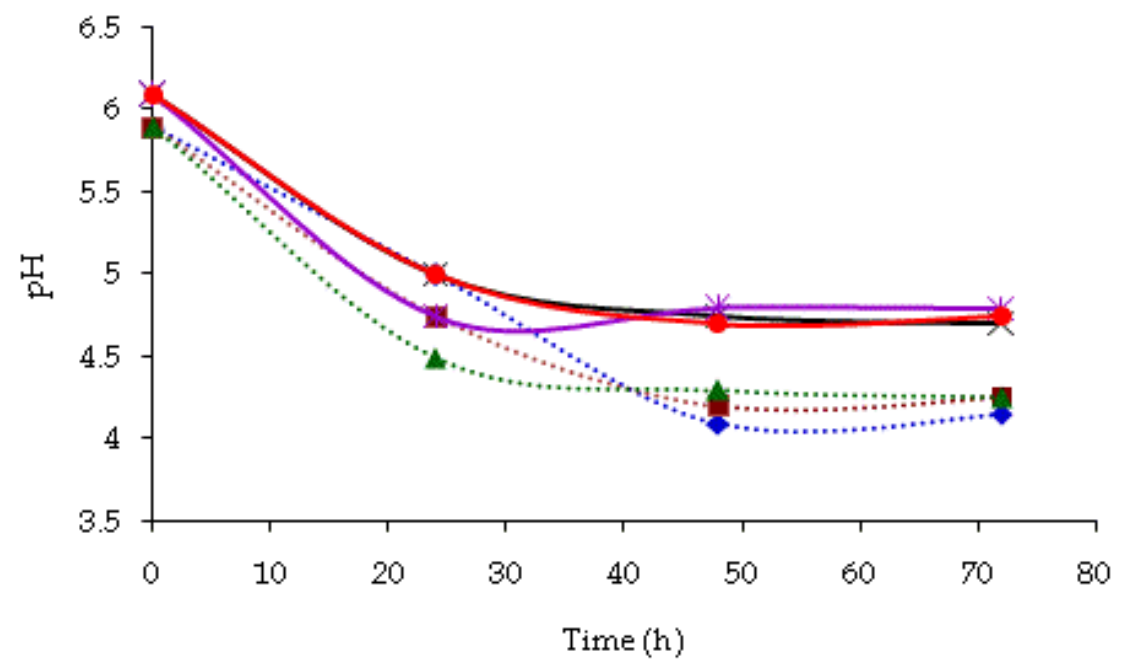

Figure 4. $\mathrm{pH}$ during ripening of Nham control at $25^{\circ} \mathrm{C}(\bullet), 30^{\circ} \mathrm{C}(\bullet), 37^{\circ} \mathrm{C}(\Delta)$ and Nham with starters (L. plantarum + L. sake) at $25^{\circ} \mathrm{C}(\times), 30^{\circ} \mathrm{C}(*), 37^{\circ} \mathrm{C}(\bullet)$. 
Fig. 3 is represent $L^{*}$ values represent white color of Nham during ripening time and temperature at $25^{\circ} \mathrm{C}, 30^{\circ} \mathrm{C}$ and $37^{\circ} \mathrm{C}$, respectively. The results showed $\mathrm{L}^{*}$ value increased according to storage during 72 hour of ripening.

Fig. 4 shows that the initial $\mathrm{pH}$ of Nham samples ranged from 5.9 to 6.1. It then gradually decreased throughout the ripening process and there was significant difference at each time of sampling $(P<0.05)$. The $\mathrm{pH}$ value reached 4.1 to 4.8 at the end of ripening (hour 72 ). However, there was significant difference $(P<0.05)$ between the $\mathrm{pH}$ of Nham control and samples inoculated with starter cultures after 48 hour of ripening.

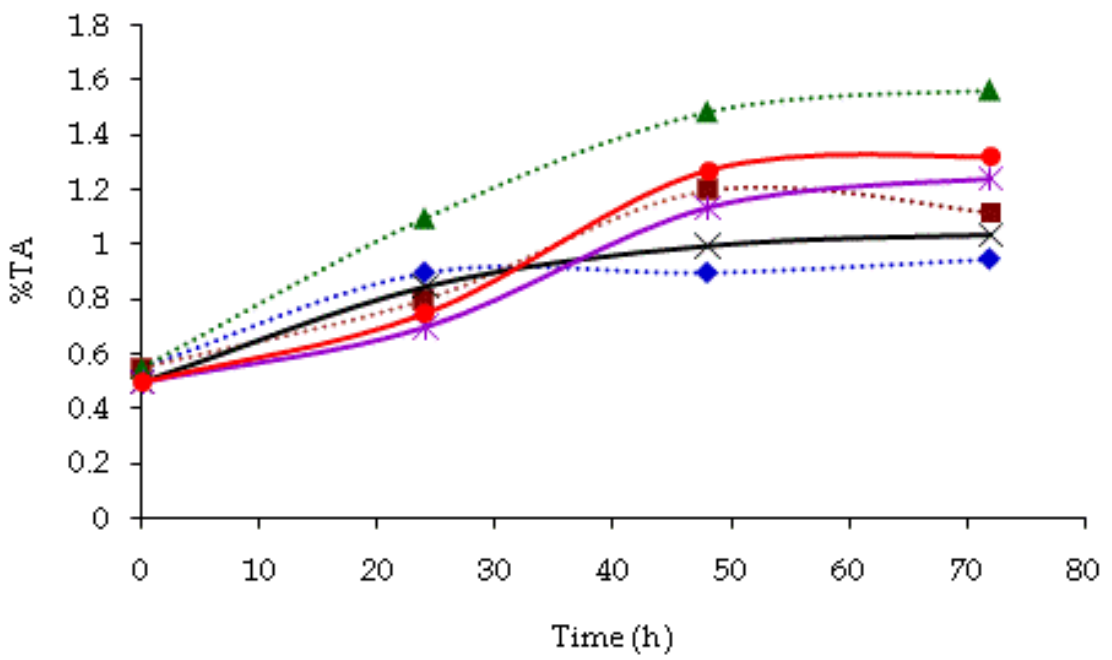

Figure 5. Total acid content during ripening of Nham control at $25^{\circ} \mathrm{C}(\bullet), 30^{\circ} \mathrm{C}(\bullet), 37^{\circ} \mathrm{C}(\boldsymbol{\Delta})$ and $\mathrm{Nham}$ with starters $\left(\right.$ L. plantarum + L. sake) at $25^{\circ} \mathrm{C}(\times), 30^{\circ} \mathrm{C}(*), 37^{\circ} \mathrm{C}(\bullet)$.

Fig. 5 shows that the initial total acid content of Nham samples ranged from 0.5 to 0.55 . It then gradually increased throughout the ripening process and there was significant difference at each time of sampling $(P<0.05)$. The total acid content of Nham control and Nham with starters reached $0.95 \%$ to $1.57 \%$ and $1.04 \%$ to $1.32 \%$ at the end of ripening (hour $72)$. However, there was significant difference $(P<0.05)$ between the total acid content of Nham control and samples inoculated with starter culture after 48 hour of ripening. The results was shown that Nham control fermented at $37^{\circ} \mathrm{C}$ contained total acid content higher than the other Nham samples.

Fig. 6 shows that TCA-soluble peptide content of Nham samples, the initial content was 9.02 $\mu \mathrm{mol} / \mathrm{g}$ dry matter. It then gradually increased throughout the ripening process. The TCAsoluble peptide content of Nham control and Nham with starters reached 23.6 to 87.2 $\mu \mathrm{mol} / \mathrm{g}$ dry matter and $24.1 \%$ to $65.2 \mu \mathrm{mol} / \mathrm{g}$ dry matter, respectively, at the end of ripening (hour 72). However, there was not significant difference $(P<0.05)$ between the TCA-soluble peptide content of Nham control and samples inoculated with starter culture after 48 hour 


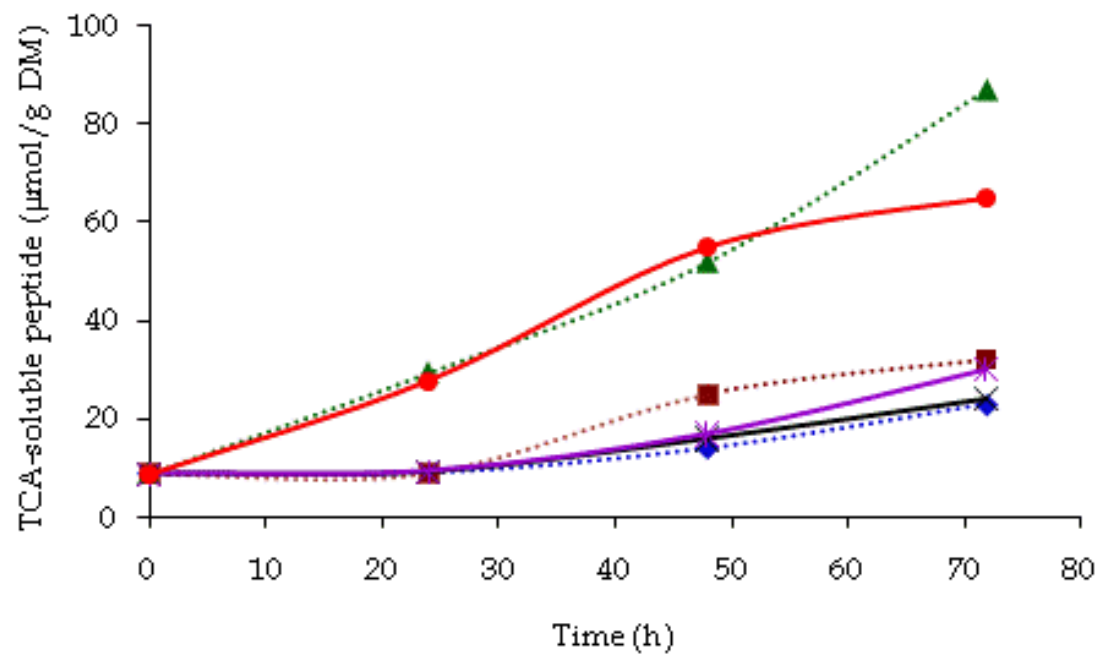

Figure 6. TCA-soluble peptide content during ripening of Nham control at $25^{\circ} \mathrm{C}(\bullet), 30^{\circ} \mathrm{C}(\bullet), 37^{\circ} \mathrm{C}(\boldsymbol{\Delta})$ and Nham with starters (L. plantarum + L. sake) at $25^{\circ} \mathrm{C}(\times), 30^{\circ} \mathrm{C}(*), 37^{\circ} \mathrm{C}(\bullet)$.

of ripening at each ripening temperature, and 72 hour of ripening at $25 \mathrm{C}$ and $30 \mathrm{C}$. The results was shown that Nham control fermented at $37^{\circ} \mathrm{C}$ contained TCA-soluble peptide content higher than the other Nham samples after ripening for 72 hour.

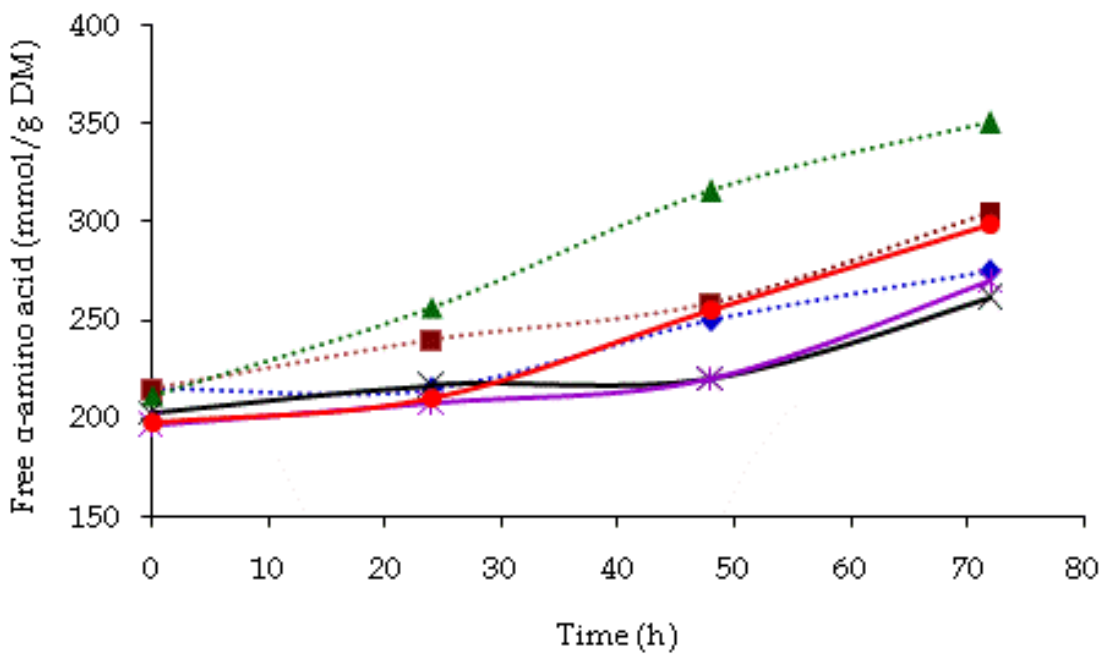

Figure 7. Free $\alpha$-amino acid content during ripening of Nham control at $25^{\circ} \mathrm{C}(\bullet), 30^{\circ} \mathrm{C}(\bullet), 37^{\circ} \mathrm{C}(\boldsymbol{\Delta})$ and Nham with starters (L. plantarum + L. sake) at $25^{\circ} \mathrm{C}(\times), 30^{\circ} \mathrm{C}(*), 37^{\circ} \mathrm{C}(\bullet)$.

Fig. 7 shows that free $\alpha$-amino acid content of Nham control samples and Nham with starters, the initial content were $216.2 \mathrm{mmol} / \mathrm{g}$ dry matter and $203.7 \mathrm{mmol} / \mathrm{g}$ dry matter, 
respectively. It then gradually increased throughout the ripening process. The free $\alpha$-amino acid content of Nham control and Nham with starters reached 275.3 to $351.6 \mathrm{mmol} / \mathrm{g}$ dry matter and 262.4 to $302.2 \mathrm{mmol} / \mathrm{g}$ dry matter, respectively, at the end of ripening (hour 72). However, there was not significant difference $(P<0.05)$ between the free $\alpha$-amino acid content of Nham control and samples inoculated with starter culture during ripening at $25^{\circ} \mathrm{C}$. The results was shown that Nham control fermented at $37^{\circ} \mathrm{C}$ contained free $\alpha$-amino acid content higher than the other Nham samples throughout the ripening process.

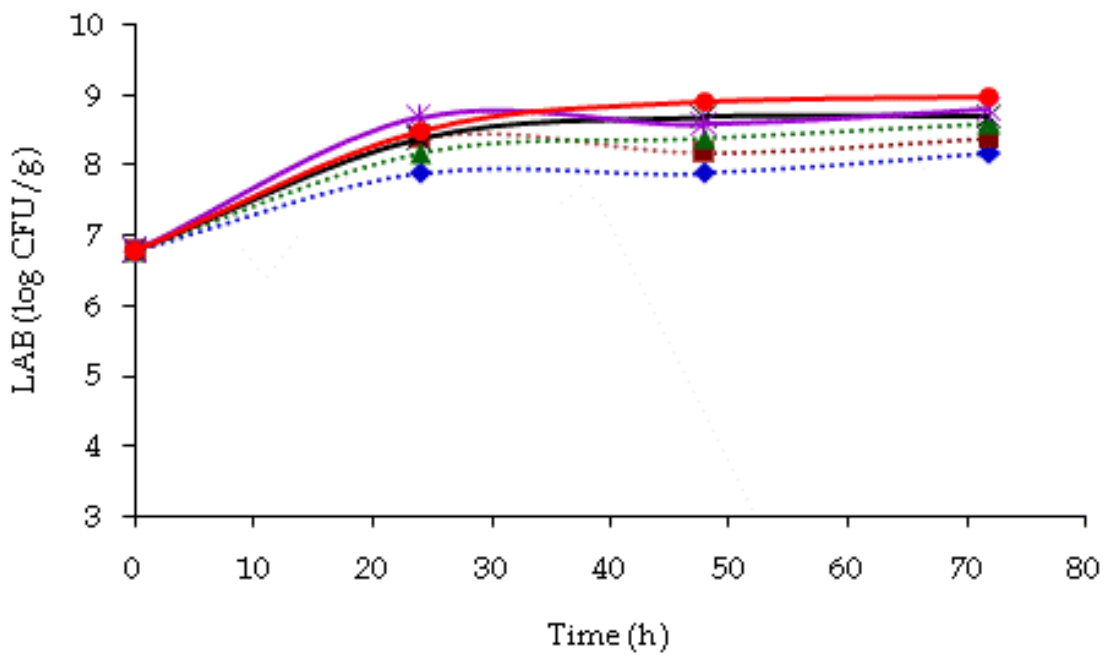

Figure 8. Total count of $\mathrm{LAB}$ during ripening of Nham control at $25^{\circ} \mathrm{C}(\bullet), 30^{\circ} \mathrm{C}(\bullet), 37^{\circ} \mathrm{C}(\boldsymbol{\Delta})$ and Nham with starters (L. plantarum + L. sake) at $25^{\circ} \mathrm{C}(\times), 30^{\circ} \mathrm{C}(*), 37^{\circ} \mathrm{C}(\bullet)$.

The differences between Nham in counts of LAB during ripening are shown in Fig. 8. LAB in Nham with starters was increase until the $72 \mathrm{~h}$ of ripening. Counts of LAB in Nham with starters $(8.7 \log \mathrm{CFU} / \mathrm{g})$ were higher $(P<0.05)$ than in Nham control $(7.7 \log \mathrm{CFU} / \mathrm{g})$.

Fig. 9 shows that cadaverine content of Nham samples, the initial content was $14.89 \mathrm{mg} / \mathrm{kg}$ dry matter. It then gradually increased throughout the ripening process. The cadaverine content of Nham control and Nham with starters reached 86.2 to $98.7 \mathrm{mg} / \mathrm{kg}$ dry matter and 42.4 to $51.6 \mathrm{mg} / \mathrm{kg}$ dry matter, respectively, at 72 hour of ripening. However, there was not significant difference $(P<0.05)$ between the cadaverine content of Nham with starters during ripening at $25^{\circ} \mathrm{C}$ and $30^{\circ} \mathrm{C}$. The results was shown that Nham control fermented at $37^{\circ} \mathrm{C}$ contained cadaverine content higher than the other Nham samples throughout the ripening process.

Fig. 10 shows that putrescine content of Nham samples, the initial content was $23.7 \mathrm{mg} / \mathrm{kg}$ dry matter. It then gradually increased throughout the ripening process and there was significant difference at each time of sampling $(P<0.05)$. The putrescine content of Nham control and Nham with starters reached 115.4 to $242.6 \mathrm{mg} / \mathrm{kg}$ dry matter and 65.2 to 98.4 $\mathrm{mg} / \mathrm{kg}$ dry matter, respectively, at 72 hour of ripening. However, there was not significant 


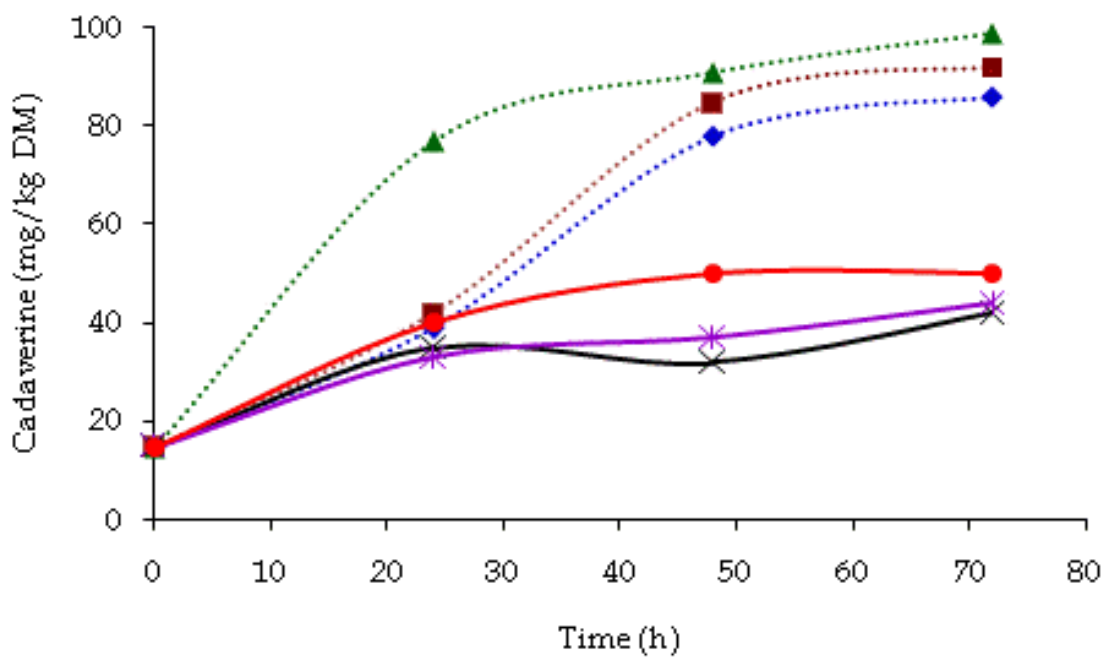

Figure 9. Cadaverine content during ripening of Nham control at $25^{\circ} \mathrm{C}(\bullet), 30^{\circ} \mathrm{C}(\bullet), 37^{\circ} \mathrm{C}(\boldsymbol{\Delta})$ and Nham with starters (L. plantarum + L. sake) at $25^{\circ} \mathrm{C}(\times), 30^{\circ} \mathrm{C}(*), 37^{\circ} \mathrm{C}(\bullet)$.

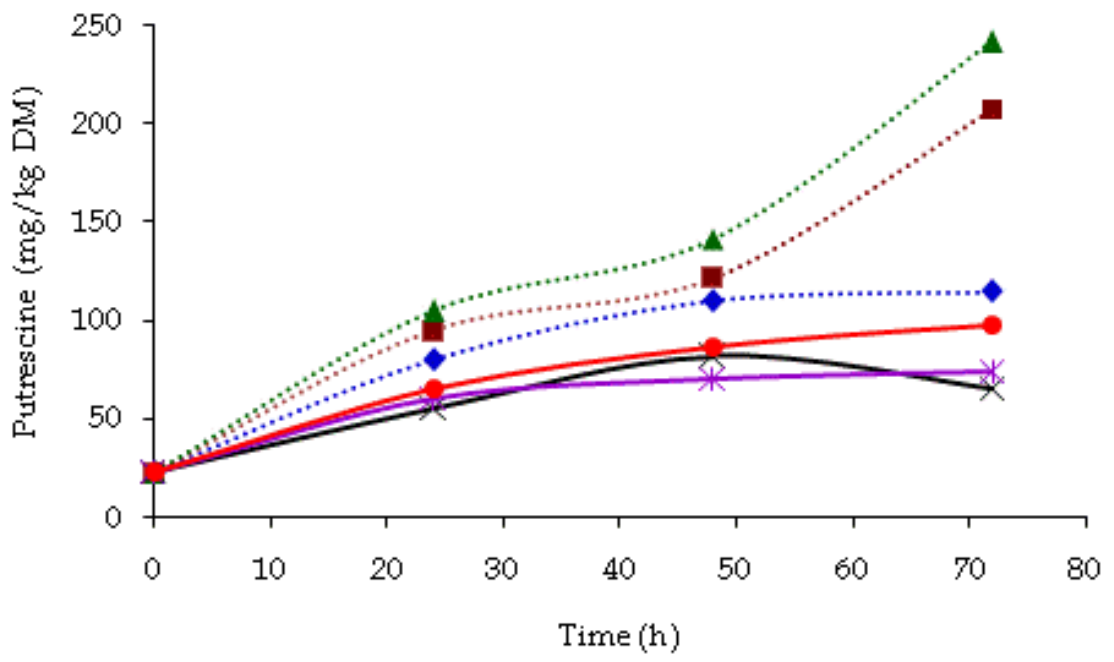

Figure 10. Putrescine content during ripening of Nham control at $25^{\circ} \mathrm{C}(\bullet), 30^{\circ} \mathrm{C}(\bullet), 37^{\circ} \mathrm{C}(\boldsymbol{\Delta})$ and Nham with starters (L. plantarum + L. sake) at $25^{\circ} \mathrm{C}(\times), 30^{\circ} \mathrm{C}(*), 37^{\circ} \mathrm{C}(\bullet)$.

difference $(P<0.05)$ between the putrescine content of Nham with starters during ripening at $25^{\circ} \mathrm{C}$ and $30^{\circ} \mathrm{C}$. The results was shown that Nham control fermented at $37^{\circ} \mathrm{C}$ contained putrescine content higher than the other Nham samples throughout the ripening process. 


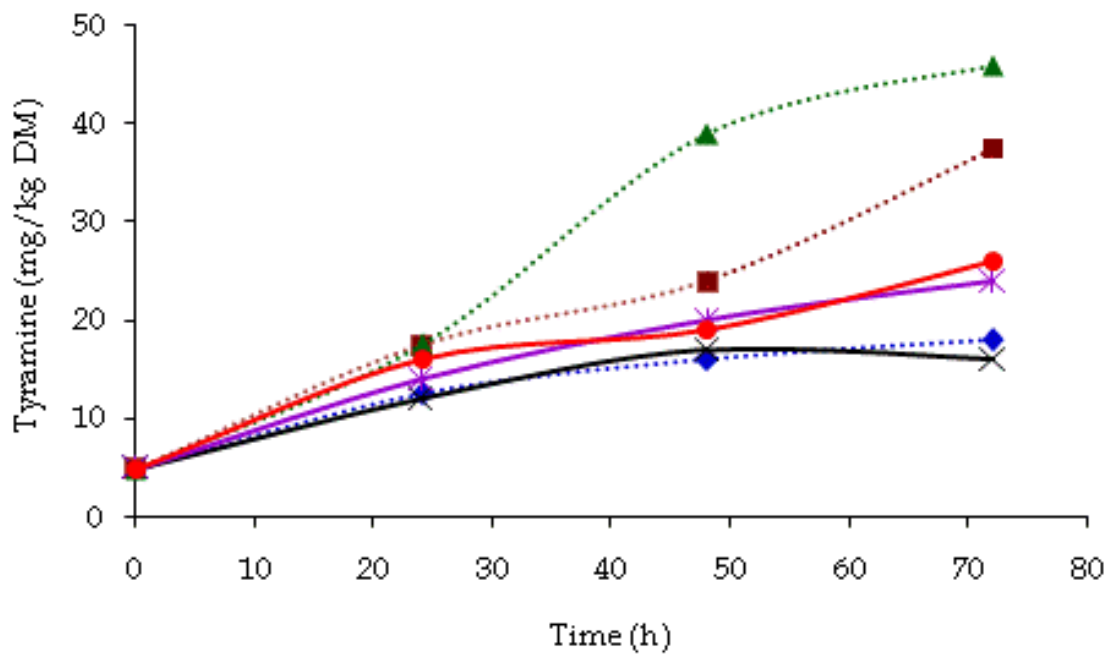

Figure 11. Tyramine content during ripening of Nham control at $25^{\circ} \mathrm{C}(\bullet), 30^{\circ} \mathrm{C}(\bullet), 37^{\circ} \mathrm{C}(\Delta)$ and Nham with starters (L. plantarum + L. sake) at $25^{\circ} \mathrm{C}(\times), 30^{\circ} \mathrm{C}(*), 37^{\circ} \mathrm{C}(\bullet)$.

Fig. 11 shows that tyramine content of Nham samples, the initial content was $5.63 \mathrm{mg} / \mathrm{kg}$ dry matter. It then gradually increased throughout the ripening process and there was significant difference at each time of sampling $(P<0.05)$. The tyramine content of Nham control and Nham with starters reached 17.6 to $46.4 \mathrm{mg} / \mathrm{kg}$ dry matter and 16.3 to 27.8 $\mathrm{mg} / \mathrm{kg}$ dry matter, respectively, at 72 hour of ripening. However, there was not significant difference $(P<0.05)$ between the tyramine content of Nham with starters during ripening at $30^{\circ} \mathrm{C}$ and $37^{\circ} \mathrm{C}$ and Nham control and Nham samples inoculated with starter culture during ripening at $25^{\circ} \mathrm{C}$. The results was shown that Nham control fermented at $37^{\circ} \mathrm{C}$ contained tyramine content higher than the other Nham samples after 48 hour of the ripening process.

The effect of temperature on BA content was evaluated (Fig. 6-9). The storage temperature of Nham with starters at $30^{\circ} \mathrm{C}$ and $37^{\circ} \mathrm{C}$ were shown higher BA oxidation comparing Nham control, a low content was observed at $25^{\circ} \mathrm{C}$. This suggested that at ripening temperature of $30^{\circ} \mathrm{C}$ and $37^{\circ} \mathrm{C}$, a strong oxidation of the AO activity of the starters was evident, whereas at $25^{\circ} \mathrm{C}$ activity was low for amino acid decarboxylase for lysine (precursor of putrescine) and tyrosine (precursor of tyramine) in Nham control.

Fig. 12 showed $\mathrm{a}^{*}$ values represent red color of Nham during stored at $15^{\circ} \mathrm{C}, 4^{\circ} \mathrm{C}$ and $25^{\circ} \mathrm{C}$. The initial $\mathrm{a}^{*}$ values of Nham control ranged from 7.0 to 8.4. The results showed $\mathrm{a}^{*}$ value increased according to 4 week storage for storage temperature at $15^{\circ} \mathrm{C}$ and $25^{\circ} \mathrm{C}$. However, there was significant decrease $(P<0.05)$ between the $\mathrm{a}^{*}$ value of $4^{\circ} \mathrm{C}$ storage of the initial 1 week storage and after 4 week of storage. For Nham with starters, the initial $\mathrm{a}^{*}$ values ranged from 7.5 to 8.5. The $\mathrm{a}^{*}$ values of Nham with starter decreased according to 4 week storage for storage temperature at $4^{\circ} \mathrm{C}$ and $15^{\circ} \mathrm{C}$. However, there was not significant difference $(P<0.05)$ between the $\mathrm{a}^{*}$ value of $25^{\circ} \mathrm{C}$ storage of the initial 1 week storage and after 4 week of storage. 


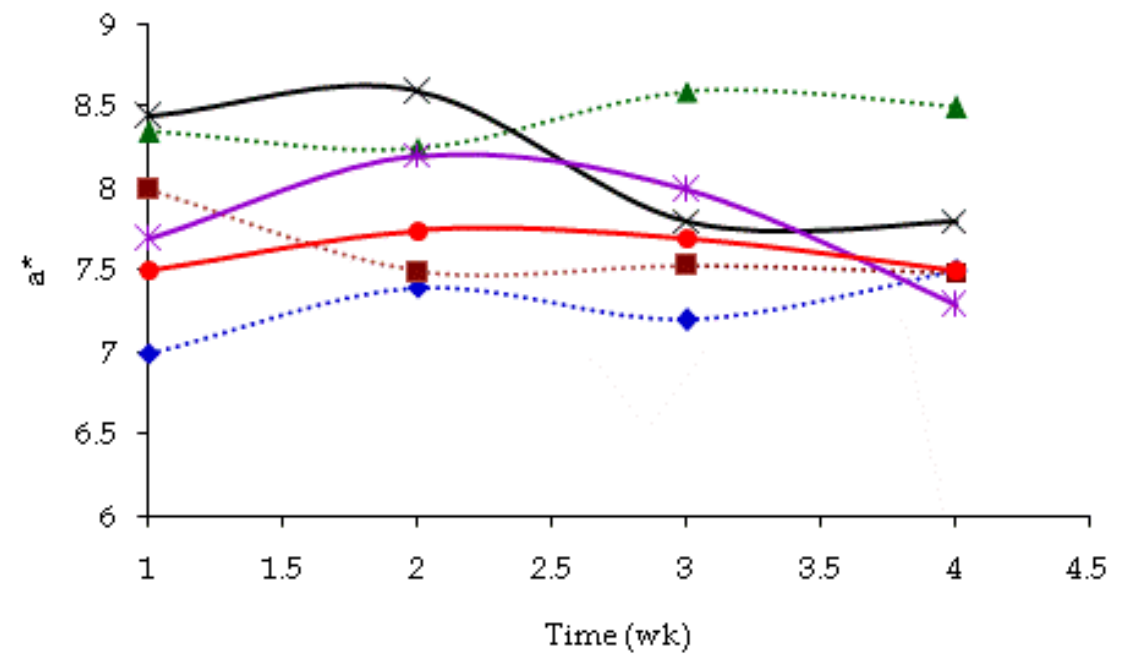

Figure 12. $\mathrm{a}^{*}$ Value during storage of Nham control at $25^{\circ} \mathrm{C}(\bullet), 30^{\circ} \mathrm{C}(\bullet), 37^{\circ} \mathrm{C}(\boldsymbol{\Delta})$ and Nham with starters (L. plantarum + L. sake) at $25^{\circ} \mathrm{C}(\times), 30^{\circ} \mathrm{C}(*), 37^{\circ} \mathrm{C}(\bullet)$.

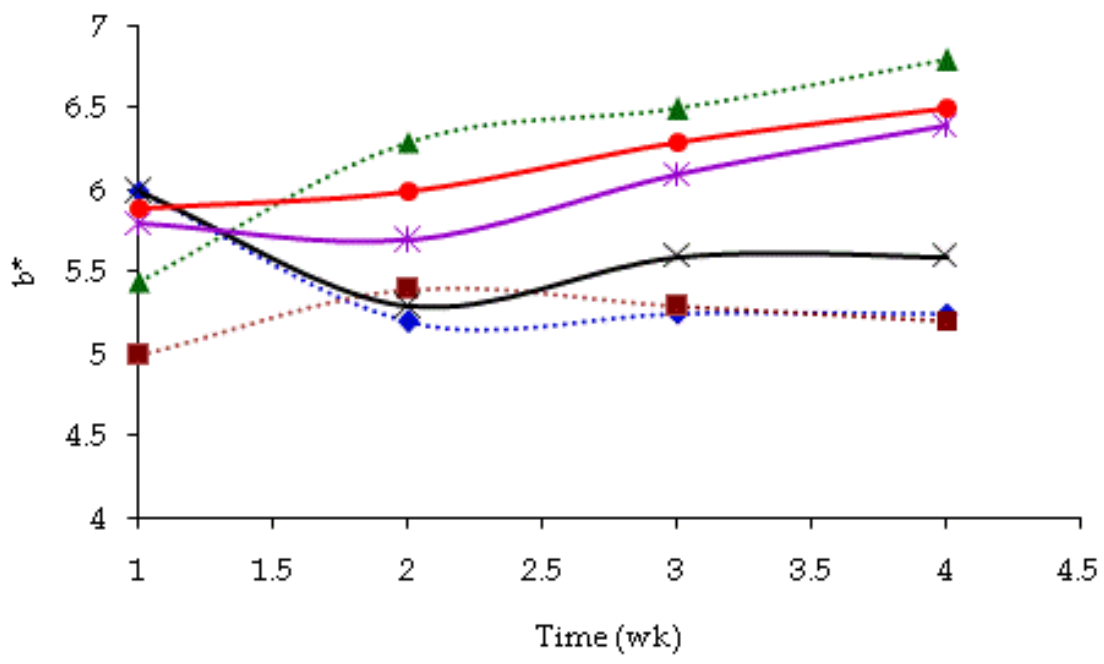

Figure 13. $b^{*}$ Value during storage of Nham control at $4^{\circ} \mathrm{C}(\bullet), 15^{\circ} \mathrm{C}(\bullet), 25^{\circ} \mathrm{C}(\boldsymbol{\Delta})$ and Nham with starters $($ L. plantarum + L. sake $)$ at $4^{\circ} \mathrm{C}(*), 15^{\circ} \mathrm{C}(\times), 25^{\circ} \mathrm{C}(\bullet)$.

Fig. 13 showed $b^{*}$ values represent yellow color of Nham during stored at $15^{\circ} \mathrm{C}, 4^{\circ} \mathrm{C}$ and $25^{\circ} \mathrm{C}$. The initial $\mathrm{a}^{*}$ values of Nham control ranged from 5.0 to 6.1. The results showed $\mathrm{a}^{*}$ value increased according to 4 week storage for storage temperature at $4^{\circ} \mathrm{C}$ and $25^{\circ} \mathrm{C}$. However, there was significant decrease $(P<0.05)$ between the $b^{*}$ value of $15^{\circ} \mathrm{C}$ storage of the initial 1 week storage and after 4 week of storage. For Nham with starters, the initial $\mathrm{a}^{*}$ 
values ranged from 5.5 to 6.2 . The $\mathrm{b}^{*}$ values of Nham with starter increased according to 4 week storage for storage temperature at $4^{\circ} \mathrm{C}$ and $25^{\circ} \mathrm{C}$. However, there was significant decrease $(P<0.05)$ between the $\mathrm{b}^{*}$ value of $15^{\circ} \mathrm{C}$ storage of the initial 1 week storage and after 4 week of storage.

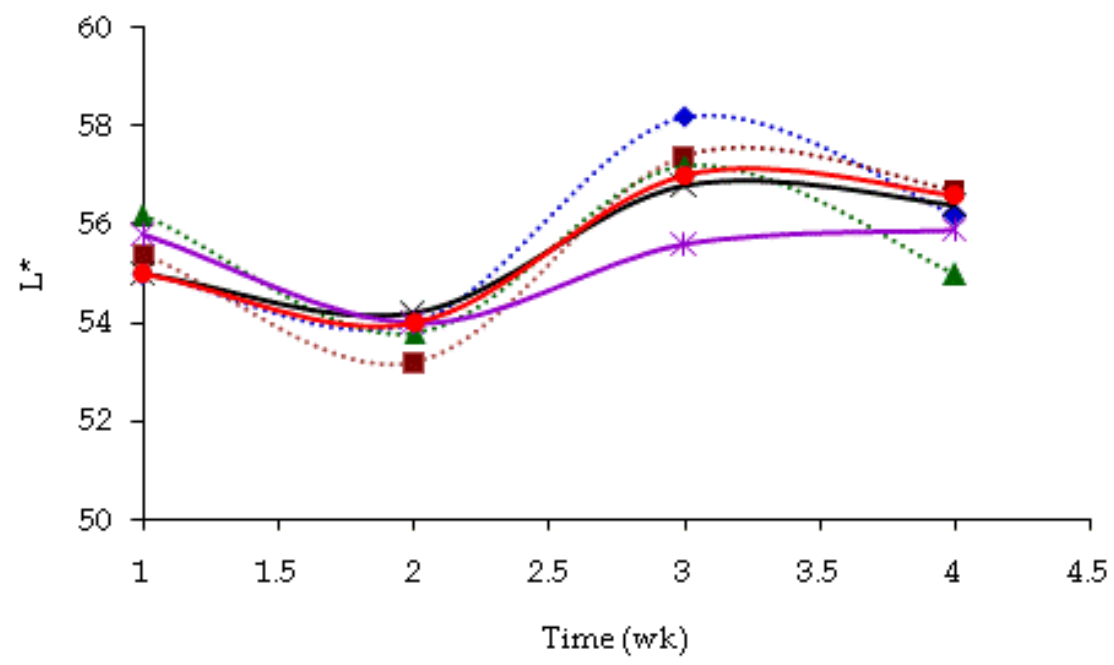

Figure 14. $\mathrm{L}^{*}$ Value during storage of Nham control at $4^{\circ} \mathrm{C}(\bullet), 15^{\circ} \mathrm{C}(\bullet), 25^{\circ} \mathrm{C}(\boldsymbol{\Delta})$ and Nham with starters (L. plantarum + L. sake) at $4^{\circ} \mathrm{C}(*), 15^{\circ} \mathrm{C}(\times), 25^{\circ} \mathrm{C}(\bullet)$.

Fig. 14 showed $\mathrm{L}^{*}$ values represent white color of Nham during stored at $15^{\circ} \mathrm{C}, 4^{\circ} \mathrm{C}$ and $25^{\circ} \mathrm{C}$. The initial $\mathrm{a}^{*}$ values of Nham control ranged from 55.1 to 56.4 . The results showed $\mathrm{L}^{*}$ value decreased after 2 week storage and then increased after 3 week storage for each storage temperature. However, there was not significant difference $(P<0.05)$ between the $\mathrm{L}^{*}$ value of $25^{\circ} \mathrm{C}$ storage of the initial 1 week storage and after 4 week of storage. For Nham with starters, the initial $L^{*}$ values ranged from 55.0 to 55.6. The $L^{*}$ values of Nham with starter decreased after 2 week storage then the $\mathrm{L}^{*}$ values increased after 3 week storage for each storage temperature and after 4 week storage at $15^{\circ} \mathrm{C}$ and $25^{\circ} \mathrm{C}$, the $\mathrm{L}^{*}$ value was significant increased. However, there was no significant difference $(P<0.05)$ between the $L^{*}$ value of $4^{\circ} \mathrm{C}$ storage of the initial 1 week storage and after 4 week of storage.

Fig. 15 shows that the initial $\mathrm{pH}$ of Nham samples ranged from 4.3 to 4.5 . It then gradually decreased throughout the storage. The $\mathrm{pH}$ value reached 4.1 to 4.5 at 4 week of storage. The $\mathrm{pH}$ values at each storage temperature of Nham with starter were higher than Nham control at each time of sampling. The results was shown that $\mathrm{pH}$ value of Nham control stored at $25^{\circ} \mathrm{C}$ was lower than the other Nham samples throughout the storage process. 


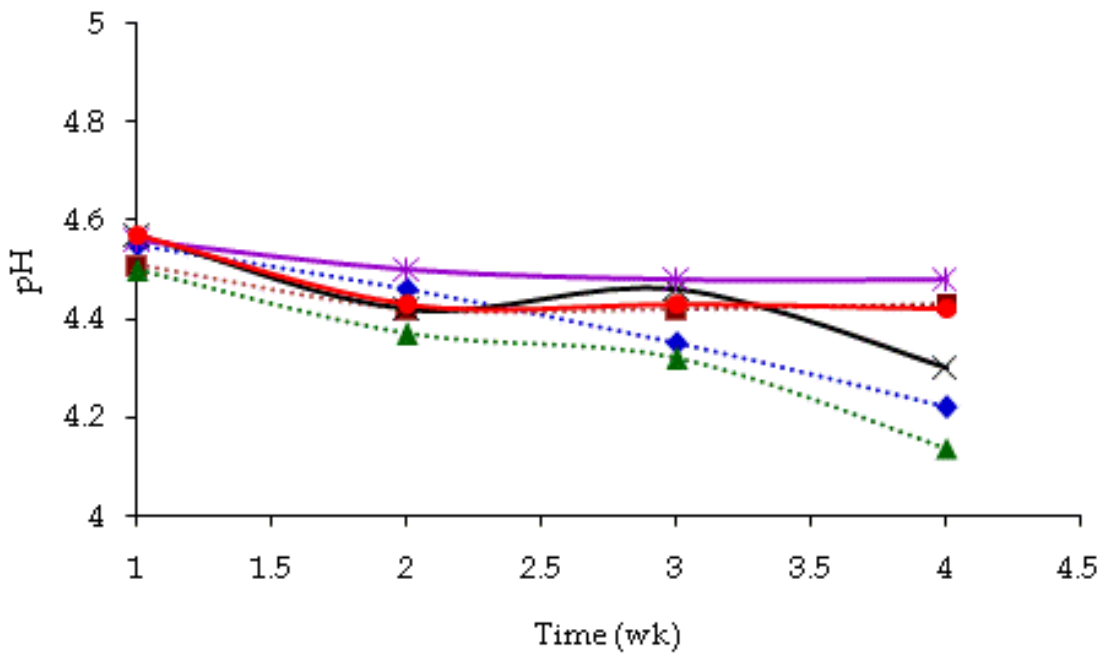

Figure 15. $\mathrm{pH}$ during storage of Nham control at $4^{\circ} \mathrm{C}(\bullet), 15^{\circ} \mathrm{C}(\bullet), 25^{\circ} \mathrm{C}(\boldsymbol{\Delta})$ and Nham with starters (L. plantarum + L. sake) at $4^{\circ} \mathrm{C}(*), 15^{\circ} \mathrm{C}(\times), 25^{\circ} \mathrm{C}(\bullet)$.

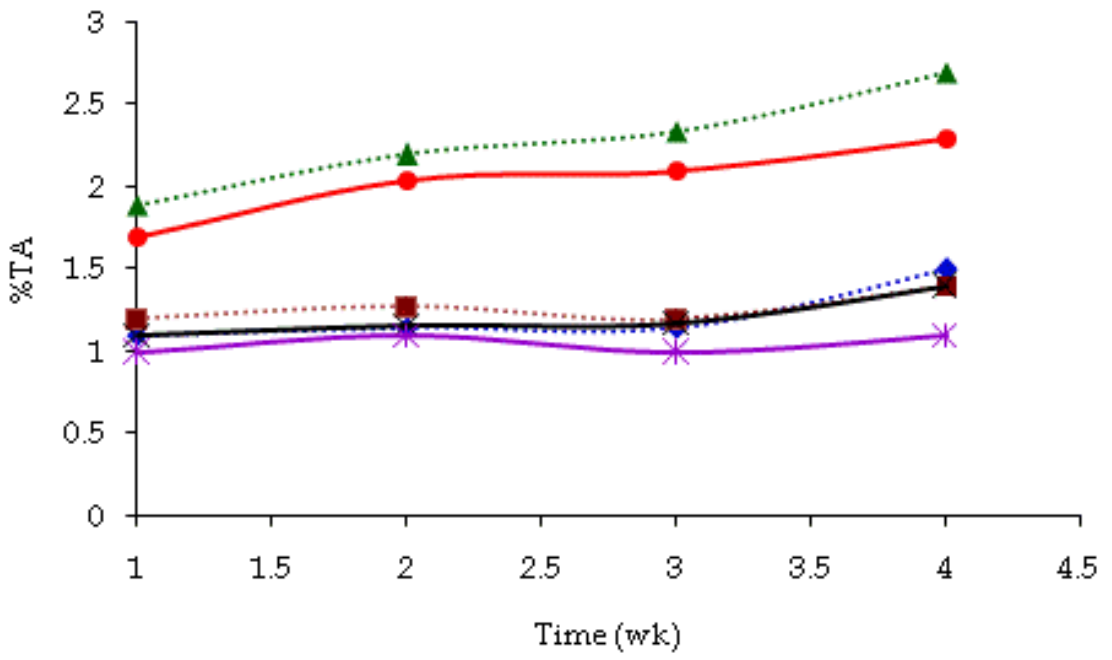

Figure 16. Total acid content during storage of Nham control at $4^{\circ} \mathrm{C}(\bullet), 15^{\circ} \mathrm{C}(\bullet), 25^{\circ} \mathrm{C}(\boldsymbol{\Delta})$ and Nham with starters (L. plantarum + L. sake) at $4^{\circ} \mathrm{C}(*), 15^{\circ} \mathrm{C}(\times), 25^{\circ} \mathrm{C}(\bullet)$.

Fig. 16 shows that the initial total acid content of Nham samples ranged from 1.1 to 1.7. It then gradually increased throughout the ripening process and there was significant difference at each time of sampling $(P<0.05)$. The total acid content of Nham control and Nham with starters reached $1.14 \%$ to $2.72 \%$ and $1.04 \%$ to $2.32 \%$ at 4 week of storage, respectively. However, there was not significant difference $(P<0.05)$ between the total acid 
content of Nham control stored at $4^{\circ} \mathrm{C}$ and $15^{\circ} \mathrm{C}$ and Nham with starters stored at $15^{\circ} \mathrm{C}$ and from the results, the total acid content of Nham with starters stored at $4^{\circ} \mathrm{C}$ was not significant difference $(P<0.05)$ during storage process. The total acid content of Nham control stored at $25^{\circ} \mathrm{C}$ was higher than the other Nham samples throughout the storage process.

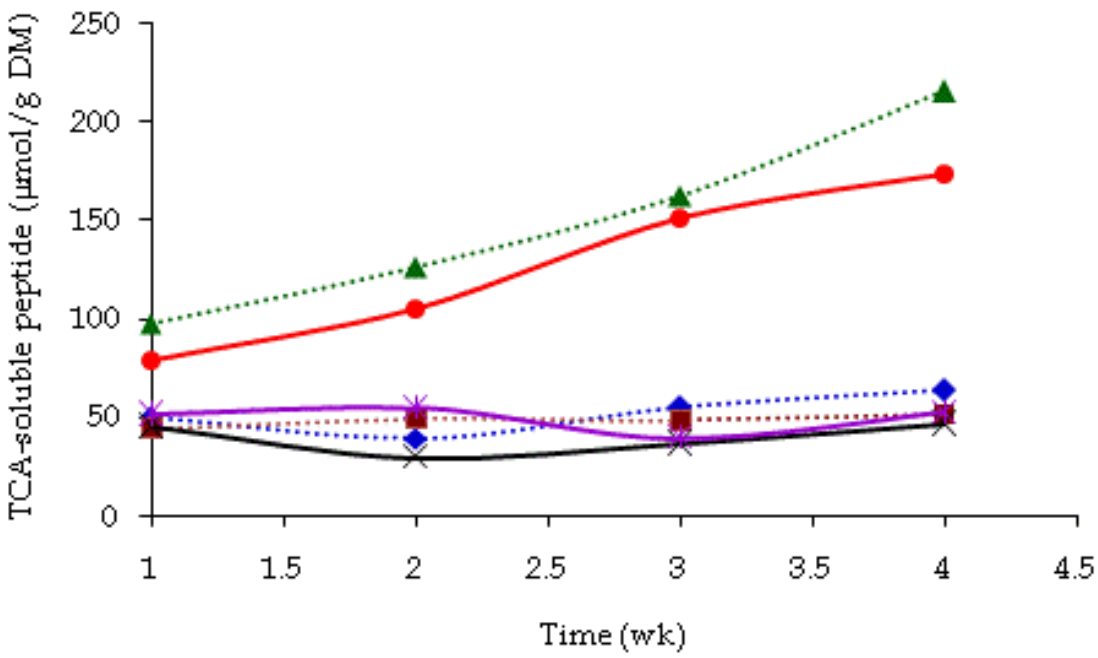

Figure 17. TCA-soluble peptide during storage of Nham control at $4^{\circ} \mathrm{C}(\bullet), 15^{\circ} \mathrm{C}(\bullet), 25^{\circ} \mathrm{C}(\boldsymbol{\Delta})$ and Nham with starters (L. plantarum + L. sake) at $4^{\circ} \mathrm{C}(*), 15^{\circ} \mathrm{C}(\times), 25^{\circ} \mathrm{C}(\bullet)$.

Fig. 17 shows that the TCA-soluble peptide of Nham control and Nham with starters ranged from 45.2 to 98.4 and 46.3 to $79.6 \mu \mathrm{mol} / \mathrm{g}$ dry matter, respectively. Nham control and Nham with starters stored at $25^{\circ} \mathrm{C}$ showed gradually increased throughout the storage process and there was significant difference at each time of sampling $(P<0.05)$. The TCA-soluble peptide of Nham control and Nham with starters stored at $4^{\circ} \mathrm{C}$ and $15^{\circ} \mathrm{C}$. However, there was not significant difference $(P<0.05)$ between the TCA-soluble peptide of Nham control and samples inoculated with starters culture throughout the storage process at $4^{\circ} \mathrm{C}$ and $15^{\circ} \mathrm{C}$. From the results, the TCA-soluble peptide of Nham control stored at $25^{\circ} \mathrm{C}$ was higher than the other Nham samples throughout the storage process.

Fig. 18 shows that free $\alpha$-amino acid content of Nham control samples and Nham with starters, the initial ranged from 342.3 to 603.4 and 346.6 to $507.2 \mathrm{mmol} / \mathrm{g}$ dry matter, respectively. It then gradually increased throughout the storage process at $15^{\circ} \mathrm{C}$ and $25^{\circ} \mathrm{C}$ and there was significant difference at each time of sampling $(P<0.05)$. The free $\alpha$-amino acid content of Nham control and Nham with starters reached 375.2 to $1867.6 \mathrm{mmol} / \mathrm{g}$ dry matter and 359.4 to $1252.4 \mathrm{mmol} / \mathrm{g}$ dry matter, respectively, at 4 week of storage. However, there was not significant difference $(P<0.05)$ between the free $\alpha$-amino acid content of Nham control and samples inoculated with starters during storage at $4^{\circ} \mathrm{C}$. The results was shown that Nham control stored at $25^{\circ} \mathrm{C}$ contained free $\alpha$-amino acid content higher than the other Nham samples after 3 week storage. 


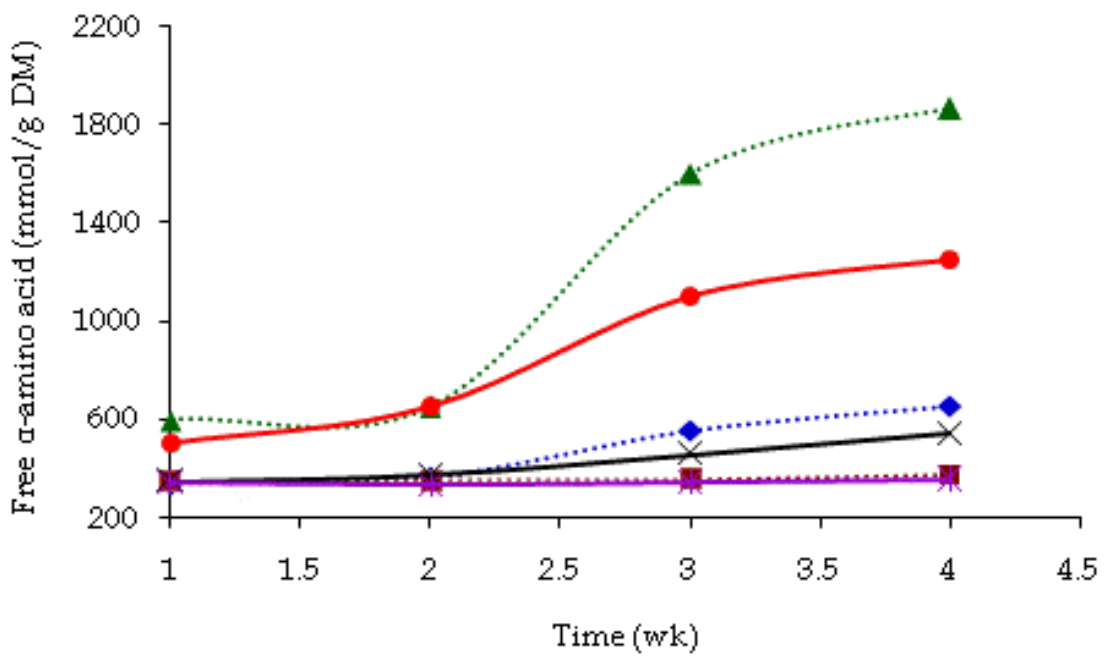

Figure 18. Free $\alpha$-amino acid content during storage of Nham control at $4^{\circ} \mathrm{C}(\bullet), 15^{\circ} \mathrm{C}(\bullet), 25^{\circ} \mathrm{C}(\Delta)$ and Nham with starters (L. plantarum + L. sake) at $4^{\circ} \mathrm{C}(*), 15^{\circ} \mathrm{C}(\times), 25^{\circ} \mathrm{C}(\bullet)$.

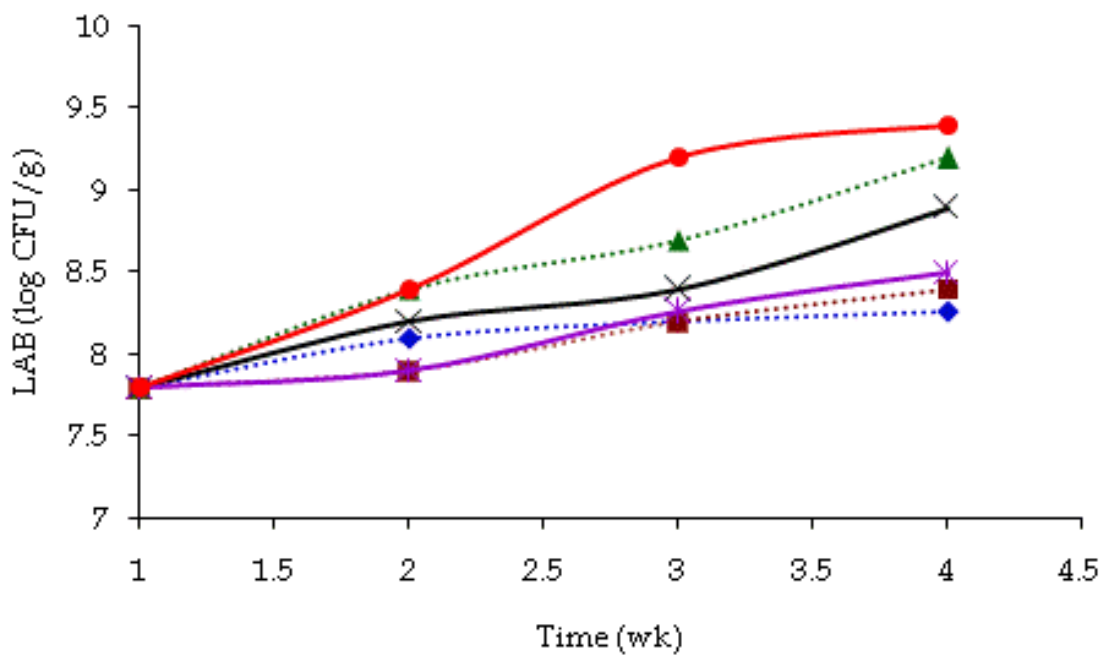

Figure 19. Total count of $\mathrm{LAB}$ during storage of Nham control at $4^{\circ} \mathrm{C}(\bullet), 15^{\circ} \mathrm{C}(\bullet), 25^{\circ} \mathrm{C}(\boldsymbol{\Delta})$ and Nham with starters (L. plantarum + L. sake) at $4^{\circ} \mathrm{C}(*), 15^{\circ} \mathrm{C}(\times), 25^{\circ} \mathrm{C}(\bullet)$.

The differences between Nham in counts of LAB during ripening are shown in Fig. 19. LAB in Nham with starters was increase until the 4 week of storage. Counts of LAB in Nham with starters stored at $25^{\circ} \mathrm{C}(9.4 \log \mathrm{CFU} / \mathrm{g})$ were higher $(P<0.05)$ than in Nham control stored at $25^{\circ} \mathrm{C}(9.1 \log \mathrm{CFU} / \mathrm{g})$. LAB counts in Nham increased steadily during storage, the dependence of the LAB counts of Nham control and Nham with starters on ripening at each 
storage temperature were significant differences. In the present study in Nham are concerned, total LAB counts in Nham with starters on 3 week of storage were higher $(P<$ $0.05)$ in comparison with the Nham control produced at the same storage temperature. An increase of $\mathrm{LAB}$ in Nham with starters until 3 week of storage and consecutive increase till 4 week of storage was significant. LAB of Nham with starters produced increase steadily during ripening and stored at different temperatures, however, at $4^{\circ} \mathrm{C}$ storage, $\mathrm{LAB}$ counts storage was not different significant.

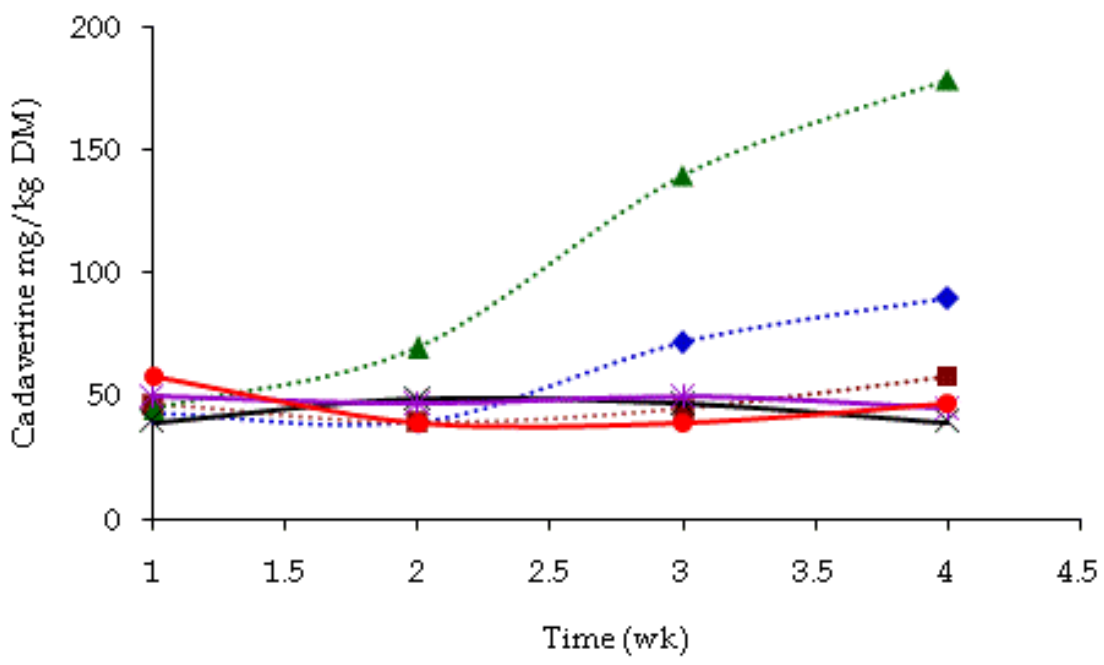

Figure 20. Cadaverine content during storage of Nham control at $4^{\circ} \mathrm{C}(\bullet), 15^{\circ} \mathrm{C}(\bullet), 25^{\circ} \mathrm{C}(\boldsymbol{\Delta})$ and Nham with starters (L. plantarum + L. sake) at $4^{\circ} \mathrm{C}(*), 15^{\circ} \mathrm{C}(\times), 25^{\circ} \mathrm{C}(\bullet)$.

Fig. 20 shows that cadaverine content of Nham samples, the initial ranged from 43.7 to 58.2 $\mathrm{mg} / \mathrm{kg}$ dry matter. In Nham control stored at $15^{\circ} \mathrm{C}$ and $25^{\circ} \mathrm{C}$, it then gradually increased throughout the storage process. The cadaverine content of Nham control and Nham with starters reached 58.4 to $91.2 \mathrm{mg} / \mathrm{kg}$ dry matter and 41.6 to $47.3 \mathrm{mg} / \mathrm{kg}$ dry matter, respectively, at 72 hour of storage. However, there was not significant difference $(P<0.05)$ between the cadaverine content of Nham with starters during stored at $4^{\circ} \mathrm{C}$. The results was shown that Nham control stored at $25^{\circ} \mathrm{C}$ contained cadaverine content higher than the other Nham samples throughout the storage process and there was significant decreased $(P<0.05)$ in the cadaverine content of Nham with starters stored at $25^{\circ} \mathrm{C}$ for 4 week.

Fig. 21 shows that putrescine content of Nham control and Nham with starters, the initial ranged from 124.6 to $176.3 \mathrm{mg} / \mathrm{kg}$ dry matter and 126.2 to $98.3 \mathrm{mg} / \mathrm{kg}$ dry matter. Nham control stored at $4^{\circ} \mathrm{C}, 15^{\circ} \mathrm{C}$ and $25^{\circ} \mathrm{C}$ gradually increased throughout the storage process. The putrescine content of Nham control and Nham with starters reached 175.3 to 339.4 $\mathrm{mg} / \mathrm{kg}$ dry matter and 122.6 to $129.3 \mathrm{mg} / \mathrm{kg}$ dry matter, respectively, at 4 week of storage. However, there were significant increase $(P<0.05)$ between the putrescine content of Nham with starters at each storage temperature for 2 week and then the putrescine content 
decreased and there was not significant difference $(P<0.05)$ between the putrescine content of Nham with starters after 3 week storage. The results were shown that Nham control stored at $25^{\circ} \mathrm{C}$ contained putrescine higher than the other Nham samples throughout the storage process.

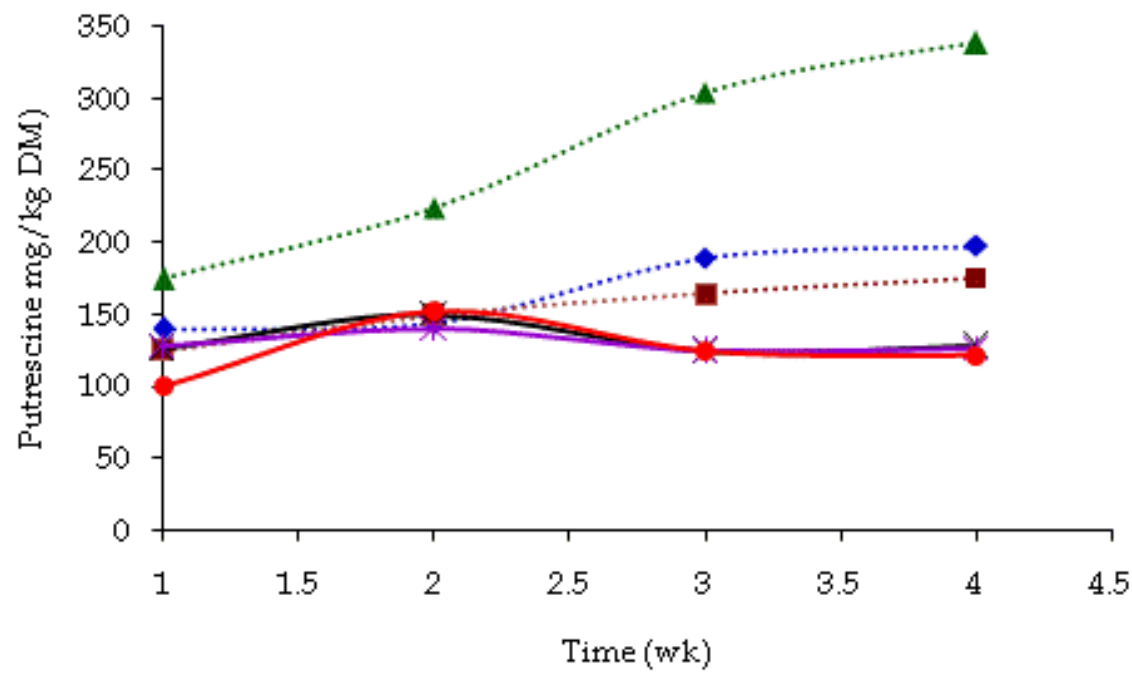

Figure 21. Putrescine content during storage of Nham control at $4^{\circ} \mathrm{C}(\bullet), 15^{\circ} \mathrm{C}(\bullet), 25^{\circ} \mathrm{C}(\boldsymbol{\Delta})$ and Nham with starters (L. plantarum + L. sake) at $4{ }^{\circ} \mathrm{C}(*), 15^{\circ} \mathrm{C}(\times), 25^{\circ} \mathrm{C}(\bullet)$.

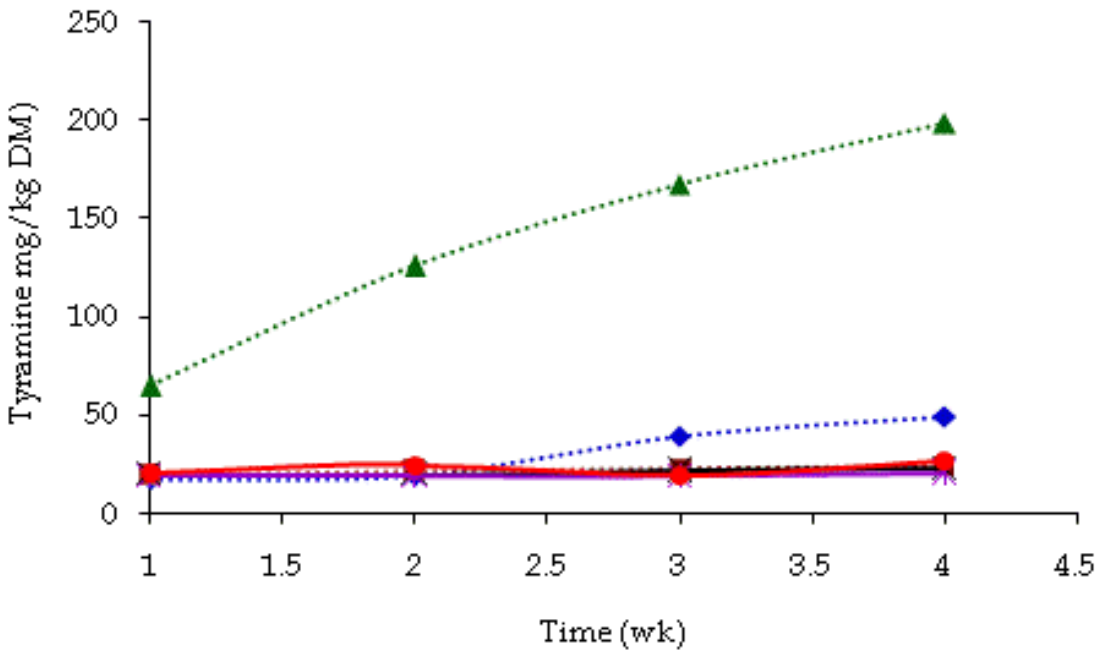

Figure 22. Tyramine content during storage of Nham control at $4^{\circ} \mathrm{C}(\bullet), 15^{\circ} \mathrm{C}(\bullet), 25^{\circ} \mathrm{C}(\boldsymbol{\Delta})$ and Nham with starters (L. plantarum + L. sake) at $4^{\circ} \mathrm{C}(*), 15^{\circ} \mathrm{C}(\times), 25^{\circ} \mathrm{C}(\bullet)$. 
Fig. 22 shows that tyramine content of Nham control and Nham with starters, the initial ranged from 18.2 to $65.3 \mathrm{mg} / \mathrm{kg}$ dry matter and 19.2 to $22.4 \mathrm{mg} / \mathrm{kg}$ dry matter. Nham control stored at $15^{\circ} \mathrm{C}$ and $25^{\circ} \mathrm{C}$ gradually increased during storage process. The tyramine content of Nham control and Nham with starters reached 25.2 to $198.6 \mathrm{mg} / \mathrm{kg}$ dry matter and 21.4 to $27.6 \mathrm{mg} / \mathrm{kg}$ dry matter, respectively, at 4 week of storage. There was not significant difference $(P<0.05)$ between the tyramine content of Nham control stored at $4^{\circ} \mathrm{C}$ and Nham with starters at each storage temperature during storage time. The results was shown that Nham control stored at $25^{\circ} \mathrm{C}$ contained tyramine higher than the other Nham samples throughout the storage process.

One of the most important factors influencing BA formation in Nham is starter culture (Maijalaet al., 1995). Increase of LAB starters culture in Nham resulted in overgrowth more than the microflora and LAB producing BAs in Nham control and caused decrease in BA contents in Nham during ripening and storage. A higher amount of BAs was formed in the Nham control than in starters culture-ones. However, strains of the starters showed lower decarboxylase activity (lower total free amino acid content in Nham) in comparison with the Nham control. Moreover, from the fact that BA production increased in Nham control after the ripening was finished and Nham was stored at the $15^{\circ} \mathrm{C}$ and $25^{\circ} \mathrm{C}$, which coincided with the temporary increase of total $\mathrm{LAB}$, the presence of spontaneous decarboxylating microflora can be inferred, and the refrigerated storage should be recommended. Simultaneously, higher concentration of BAs was found in Nham fermented at high $30^{\circ} \mathrm{C}$ and $37^{\circ} \mathrm{C}$ as compared to $25^{\circ} \mathrm{C}$ at the end of ripening. However, as regards to the strongly hypothetical effects of some substances in the Nham spicing mixtures in connection with the BA formation, more research is needed. Decarboxylase activities present in microflora in Nham are influenced by pH, temperature (Gardini et al., 2001; Silla-Santos, 1996; Suzzi and Gardini, 2003). The decarboxylation of FAAs to BAs was found to be inhibited by low $\mathrm{pH}$ (Gardini et al., 2001). Though amino acid decarboxylase activities usually have acid $\mathrm{pH}$ optimum (Gale, 1946), the $\mathrm{pH}$ rise could favour the cell yield and growth (Maijala, 1994) of decarboxylase-positive microflora.

\subsection{BAs contents of Nham}

Occurrence of toxic compounds such as BAs is favoured by a high concentration of substrates (i.e., free amino acids) together with environmental and technological factors (e.g. $\mathrm{NaCl}$ content, chemico-physical variables, hygienic procedure adopted during production) promoting microbial growth and the decarboxylase activity of microorganisms (Silla-Santos, 1996). In this study, a high correlation among total BAs and total FAAs content was observed. Temperature markedly influences the formation of BAs, and at $15^{\circ} \mathrm{C}$ decarboxylases might be still active (Bover-Cid et al., 2001). During storage, the more temperature exceeds $14-15^{\circ} \mathrm{C}$ the more decarboxylase activities might release BAs from FAAs. In this respect, processing procedures for Nham based on low salt addition, high ripening temperatures (over $20^{\circ} \mathrm{C}$ ), may favour proteolytic and decarboxylase activities. The high values of cadaverine, putrescine and tyramine detected in some Nham, may be ascribed to inadequate microflora and LAB producing BAs reduction occurring in some Nham control (Fig. 9- Fig. 11 and Fig. 20- Fig. 22). 
The toxicological level of BAs depends on the individual characteristics and the presence of other amines (Brink et al., 1990; Halasz et al., 1994). Toxic doses of tyramine in foods were reported in the range $100-800 \mathrm{mg} / \mathrm{kg}$, but average amounts of tyramine detected in analysed samples (Fig. 9- Fig. 11 and Fig. 20- Fig. 22) were below this range, even if in case of a few samples, the $100 \mathrm{mg} / \mathrm{kg}$ value was exceeded. Putrescine has been regarded as not toxic by itself, but as a potentiator for the toxic effect of tyramine and histamine if present (Hui and Taylor, 1985). However, it was probable to demonstrate significant relationship between the concentration of a specific FAA and its corresponding BA in meat products (Eerola et al., 1998). Fig. 9- Fig. 11 and Fig. 20- Fig. 22 shows the BAs content of Nham evidence the effect of starters on the decrease of the BAs occurrence in Nham after ripening and storage. Histamine was always below the minimum detectable, in spite of the abundance of their precursors (histidine) released during the process; phenylethylamine was also not detected.

The concentration of tyramine was high in Nham control while low concentration, of their precursors (tyrosine) released during the process. Moreover, tryptamine resulted absent in all the investigated samples. The sum of vasoactive BAs, VBA; (tyramine, phenylethylamine, histamine and tryptamine) lower than $200 \mathrm{mg} / \mathrm{Kg}$ has been suggested by Eerola et al. (1998) as a quality index (VBA index) for ripened meat products. It is interesting to note that the computed VBA index of Nham with starters with differently processed resulted appreciable samples $(3.70 \pm 2.46 \mathrm{mg} / \mathrm{Kg})$. These results could be related to the specific characteristics of the product as well as to the process conditions adopted that could, in general, have limited the growth and activity of amino acid decarboxylase positive microorganisms (Suzzi and Gardini, 2003). Cadaverine, putrescine and tyramine were found in high amounts in Nham control. However, the occurrence of BAs in Nham control, and after the storage could be due to the microflora and LAB producing BAs that could have favoured their formation during ripening and storage. During ripening and storage of Nham control, putrescine and cadaverine show a marked increase with high amounts of their precursor, arginine and lysine, respectively, were detected. In fact, arginine may generate putrescine both via arginine deiminase pathway (ADI) leading to ornithine (Montel and Champomier, 1987) and their subsequent decarboxylation to putrescine, and via arginine decarboxylation to agmatine followed by deamination to putrescine and removal of urea (Moreno-Arribas et al., 2003). It seems reasonable to postulate that the large amounts of arginine could be the source of putrescine, which subsequently may be converted in spermine and spermidine by transamination reactions (Lehninger et al., 1999).

\subsection{FAAs contents of Nham}

FAAs were reported in Table 2- Table 5 as net amounts (mmol/g dry matter) in order to investigate the differences in contents due to starters in Nham during ripening and storage. FAAs were compared to evaluate if the extended storage times gave a similar increase in all of them or different patterns were detectable. Most single FAAs increased during ageing with particular reference to the lipophylic ones; a rise in lypophilic valine, phenylalanine and tryptophan processed following a traditional prolonged way (Ruiz et al., 1999). In the present study, stored Nham showed a FAA pattern enriched with glutamic acid, alanine, 
arginine, cysteine, serine, threonine and glycine, most FAAs displayed a rise during the extended storage. Arginine found in the most stored Nham was increase, due to changing of its content by proteolysis; and rise in arginine in stored Nham control was higher than stored Nham with starters. Arginine hydrolysis could be hydrolysed via the arginine deiminase pathway (ADI) leading to ammonia and ornithine. It seemed reasonable to postulate that ADI pathway enzymes (arginine deiminase and ornithine transcarbamylase) could be still active during storage times. Arginine catabolism, may be regarded as a source of the BA putrescine both via ADI ornithine generation (Montel and Champomier, 1987) and subsequent decarboxylation to putrescine, and via arginine decarboxylation to agmatine followed by deamidation to putrescine and removal of urea (Moreno-Arribas et al., 2003). The presence in Nham of environmental conditions suitable for decarboxylase activities together with large amounts of arginine may be consistent with the increase in putrescine.

The evolution during incubation/storage of the total free amino acid content, in both the Nham control and after inoculation with either of the two Lactobacillus strains selected, is shown in Table 2- Table 5, and encompassed 17 different amino acids. The control Nham showed the highest concentration of total amino acids at a $5 \%$ level of significance. The contents of total amino acids in Nham inoculated with L. plantarum and L. sake, increased throughout time, but at lower rates than the control. The contents of free amino acids and BAs in control and experimental Nham increase significantly throughout incubation/storage. However, specific lactic acid strains of the Lactobacillus genus can effectively prevent BAs from building-up excessively, putrescine (for quantitative reasons, owing to its level). This may lead to a favourable contribution to public health, especially in regions where Nham is frequently included in the diet. To have an overall evolution index of the proteases action in the Nham during processing the TCA-soluble peptide was evaluated (Fig. 6 and Fig. 17) (Toldr, 2005). More intense proteolytic activity occurred in the Nham control. The TCA-soluble peptide values of Nham control are quite high compared to those generally observed in other Nham with starters. This could be attributed to the microflora in Nham control slightly higher proteolytic activity during the process, in comparison with those Nham applied with starters. Proteolysis contributes to texture by breakdown of the muscle structure (Monin et al., 1997).

Table 2- Table 5 show the FAAs content of Nham during ripening and storage arginine and glutamic acid were the FFAs most representative; after ripening and storage a marked increase of alanine was observed. Table 6 shows the effect of the starters treatment on the evolution of the FAAs pattern of the Nham investigated during the ripening and storage: a significant increase in the concentration of all FAAs with respect to their initial occurred in Nham control and Nham with starters, resulting from the aminopeptidases activity of meat (Toldr, 2006) as well as microbial proteases (Dur et al., 2004; Molina and Toldrá, 1992; Rodrguez et al., 1998; Scannell et al., 2004). Moreover, starters in Nham seems to affect the production of some amino acids (Table 6). A lower concentration of lysine, threonine, glycine and proline was detected, after storage, in Nham processed. Arginine was the most abundant amino acid in all the final products, and its level was significantly higher in Nham control than in those subjected with starters to Nham. At the end of the ripening step, 
cysteine was also present in a relative higher concentration in Nham control, whereas significant larger amounts of proline, lysine, histidine, serine and threonine were reached in Nham control samples. The different profile of FAAs observed in Nham control and Nham with starters may be due to a different evolution of reactions and processes involving both production and consumption of amino acids that occur simultaneously during the various steps of the ripening process and storage and whose combined effects could give rise to an increase or, on the contrary, to a decrease of their concentration. The aminopeptidase activity is considered the main process implied in the FFA release in meat. Moreover, free amino acids concentration could be decreased either by chemical and enzymatic reactions where they act as substrates leading to the formation of secondary products (Ruiz et al., 1999; Ventanas et al., 1992) and/or by microbial amino acid decarboxylase activity with consequent BA production (Virgili et al., 2007).

In Nham control, an effect due to higher concentration of decarboxylase than that of Nham with starters, thus, their reaction with the free amino acids causing an increase of their BA concentration in these samples.

The ripened taste could be related to lysine and glutamic acid, while isoleucine and aspartic acid are implied in acid taste and unpleasant aroma (Buscailhon et al., 1994; Flores et al., 1998). In this study, the increase in concentration of lysine and glutamic acid was observed. The changes in the contents of free amino acids observed in fermented sausages during ripening are given in Table 2. The total free amino acid contents of the Nham control and Nham with starters constituted 212.7-216.4 mmol/g and 197.2-203.4 mmol/g dry matter, respectively (before ripening) on 0 day. An increase in the content of amino acids of Nham control and Nham with starters was observed and ranged between 275.2-349.8 mmol/g and 259.8-300.3 $\mathrm{mmol} / \mathrm{g}$ dry matter during the ripening on day 3 , and a further increase up to the range of $377.6-1851.7 \mathrm{mmol} / \mathrm{g}$ and $348.1 \mathrm{nmol} / \mathrm{g}-1256.0 \mathrm{mmol} / \mathrm{g}$ dry matter of total free amino acids was observed during storage at $4^{\circ} \mathrm{C}-25^{\circ} \mathrm{C}$ of Nham control and Nham with starters ( 4 weeks). The highest total free amino acid concentration of $1867.2 \mathrm{mmol} / \mathrm{g}$ was observed with Nham control stored at $25{ }^{\circ} \mathrm{C}$ for 4 week, whereas the lowest total free amino acid concentration of $359.6 \mathrm{mmol} / \mathrm{g}$ was observed with Nham with starters stored at $25^{\circ} \mathrm{C}$ for 4 week. The hydrolysis of meat proteins generates polypeptides that can be further degraded to smaller peptides and free amino acids. This degradation can be produced by endogenous and microbial enzymes (De Masi et al., 1990; Hughes et al., 2002; Molly et al., 1997). The increase in the total free amino acid concentration was detected in all batches (Hierro et al., 1999, Bruna et al., 2000, Bolumar et al., 2001 and Hughes et al., 2002).

The main differences in the content of total free amino acids among batches were detected during 72 hour of ripening and during 4 week of storage. The amino acids in which differences, which were primarily responsible for the increase in total free amino acids during ripening, were observed were Glu (glutamic acid), Ala (alanine) and Arg (arginine) in Nham control and Nham with starters. Mateo et al. (1996) reported an increase in the total free amino acid content during the ripening. The change occurred during ripening and storage process indicating that the highest enzymatic activity took place during these stages 


\begin{tabular}{|c|c|c|c|c|c|c|c|c|c|c|c|c|c|c|c|c|c|c|c|c|}
\hline & & है। & | & & & ?ุ. & 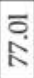 & & & & స్. & ర్రొ & ก็ & & $\begin{array}{c}0 \\
\text { ก) }\end{array}$ & รั & ? & 茴 & & 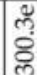 \\
\hline & & $\frac{d}{g}$ & فำ & & & تِّ. & $\begin{array}{l}\text { ठㅇ } \\
\text { 18 }\end{array}$ & & & जु & $\begin{array}{l}\text { ली } \\
\text { îे }\end{array}$ & g & శึ & & 总 & $\frac{0}{2}$ & $\stackrel{0}{\infty}$ & लొ & & \\
\hline & & ક & & Sू & & $\vec{b}$ & $\begin{array}{l}\text { ปี } \\
\text { กิ }\end{array}$ & & & & $\stackrel{\text { fr }}{+}$ & $\stackrel{\pi}{\longrightarrow}$ & $\stackrel{\text { f }}{0}$ & హ็ & กั๊ & 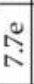 & 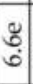 & 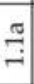 & & \\
\hline & & $\begin{array}{l}\text { ב्ञ } \\
\text { న }\end{array}$ & $\overrightarrow{\mathrm{i}}$ & 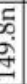 & & & $\underset{\infty}{\infty}$ & & 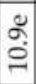 & $\begin{array}{c}y \\
\text { ले }\end{array}$ & $\underset{\substack{\tau\\
}}{ }$ & คे & مّ & & 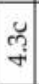 & 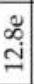 & 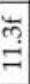 & $\mathbb{\infty}^{2}$ & & \\
\hline & & & ¿̊̃ & 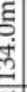 & & 3 & $\begin{array}{l}\frac{E}{+} \\
\stackrel{+}{\circ}\end{array}$ & & $\begin{array}{l}\frac{\mathrm{z}}{0} \\
\text { : }\end{array}$ & ลู้ & 点 & 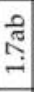 & ก็ & & $\begin{array}{l}\text { की } \\
\text { ले }\end{array}$ & $\bar{t}$ & 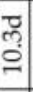 & & & \\
\hline & & & 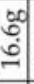 & & & $\stackrel{2}{\overrightarrow{2}}$ & & & & $\vec{v}$ & గై & g & ঙ̊ & & $\begin{array}{c}\underset{\mathrm{J}}{\mathrm{m}} \\
\mathrm{m}\end{array}$ & $\begin{array}{l}\text { సै } \\
\text { స్ }\end{array}$ & $\begin{array}{l}\vec{b} \\
\infty \\
\infty\end{array}$ & సొ & & \\
\hline & & & فी & & ली & 2 & 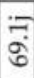 & $\begin{array}{l}\mathscr{f} \\
\underset{\infty}{0}\end{array}$ & $\begin{array}{c}\breve{a} \\
\infty \\
\infty\end{array}$ & लొ & ถે & $\stackrel{g}{\rightarrow}$ & กั๊ & & & & ڤ్ & ֻొ & & \\
\hline & & & & $\delta$ & & & & & & S & 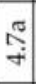 & I & $\stackrel{\text { f̊ }}{0}$ & & & ఫ़ & 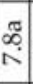 & & & \\
\hline & & & & 2 & & $\stackrel{\pi}{0}$ & & लై & న్ర్ & 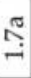 & ঙ̆ & $\stackrel{\Xi}{=}$ & $\stackrel{g}{0}$ & 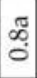 & $\begin{array}{l}\stackrel{\pi}{5} \\
\text { in }\end{array}$ & $\stackrel{\frac{2}{\pi}}{\pi}$ & 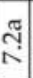 & ฮ̊ & & \\
\hline & & & ప్ & & e & $\stackrel{20}{2}$ & & & ఫ̛ & $\begin{array}{l}\text { di } \\
\text { in }\end{array}$ & 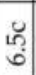 & ـ & ก็๊ & & & 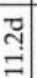 & 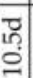 & กั & & \\
\hline & & £ & $\approx$ & ㅎ․ & & 2 & $\hbar$ & 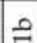 & & है & 10 & ક5 & กี & $\pi$ & -0 & $y$ & & లూ & & \\
\hline & & & 20 & 现 & & 3 & 16 & & & הู & & & $0^{\circ}$ & & $n$ & $\sigma$ & $\sigma^{\circ}$ & -1 & & \\
\hline & & & & 5 & مـ & & & & & $\overrightarrow{\mathrm{N}}$ & : & & f̊ & & $\begin{array}{l}0 \\
\text { ले }\end{array}$ & & $\begin{array}{c}0 \\
\text { ले } \\
\infty_{0}\end{array}$ & & & \\
\hline & & 3 & $\nsubseteq$ & & & & & & & & & & & & & & & & & \\
\hline & & & 20 & త్రి & & 9 & 6 & $\infty$ & & บุ & 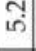 & - & $\stackrel{0}{0}$ & & $" 1$ & $\infty$ & 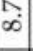 & - & & \\
\hline & & & $\bar{\tau}$ & & & तี & & & $\approx$ & (1) & $\mathbb{I}$ & ปี & ㄸำ & 2 & $\pi$ & $\pi$ & 10 & ๘ & & \\
\hline & & $\stackrel{\infty}{q}$ & - & & & $\exists$ & & & & & & & 0 & $\circ$ & & & & & & \\
\hline & & है & \% & & 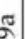 & तु & $\cong$ & $\pi$ & ఐొ & ็็ & ก็ & & g & & I & ร & $\mathbb{8}$ & & & \\
\hline & & $\triangle$ & 7 & & & - & [n] & & & & $\dot{+}$ & & 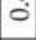 & & & & & & & \\
\hline & & & ల్ & & & & & & & & & & & & & & & & & \\
\hline & & & & & & & N & & & & in & & ? & & $\dot{m}$ & $\cong$ & $\sigma^{2}$ & 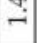 & & \\
\hline & & & م & & & & & & & & & & & & & & & & & \\
\hline & & & - & & & & & & & & & & & & & & & -1 & & \\
\hline & & & & & & & & & & & लू & ִָ̦ & ક̊ & & : & & & $\pi$ & নี & \\
\hline & & & & & & & & & & & & & & & & & & & 3 & \\
\hline
\end{tabular}

Control (without starter culture).

Results are expressed as means of three replicates in $\mathrm{mmol} / \mathrm{g}$ dry matter.

Means with different letters along rows are significantly different $(P<0.05)$.

Table 2. Amino acid content of Nham without and with starter cultures during ripening at different temperature. 
(Verplaetse et al., 1989). A major release of free amino acids at the beginning of the process have been studied in coincidence with the ripening stage (Diaz et al., 1997). This increase has been attributed to the higher temperatures applied during ripening compared to the low temperature. The most significant increases occurred in the content of Arg (arginine) in the sample. The decrease in the content of amino acids may indicate their metabolism by bacteria (Bover-Cid et al., 2000; Ordonez et al., 1999; Sekikawa et al., 2003).

\begin{tabular}{|c|c|c|c|c|c|c|c|c|}
\hline \multirow{3}{*}{$\begin{array}{c}\text { Amino } \\
\text { acid }\end{array}$} & \multicolumn{4}{|c|}{ Control } & \multicolumn{4}{|c|}{ L. plantarum + L. sake } \\
\hline & \multicolumn{4}{|c|}{ Storage time (wk) } & \multicolumn{4}{|c|}{ Storage time (wk) } \\
\hline & 1 & 2 & 3 & 4 & 1 & 2 & 3 & 4 \\
\hline Ala & $21.4 \mathrm{a}$ & $22.3 a$ & 23.0ab & $24.8 \mathrm{~b}$ & $22.1 \mathrm{a}$ & $20.7 \mathrm{a}$ & $21.1 \mathrm{a}$ & $20.2 a$ \\
\hline Arg & $151.9 \mathrm{a}$ & $154.4 \mathrm{a}$ & $154.9 \mathrm{a}$ & $168.3 b$ & $149.8 \mathrm{a}$ & $145.5 a$ & $153.8 \mathrm{a}$ & $147.2 \mathrm{a}$ \\
\hline Asp & $3.2 \mathrm{a}$ & $3.4 \mathrm{a}$ & $3.5 \mathrm{a}$ & $3.7 \mathrm{a}$ & $2.9 \mathrm{a}$ & $2.9 \mathrm{a}$ & $3.1 \mathrm{a}$ & $3.0 \mathrm{a}$ \\
\hline Cys & $18.2 \mathrm{a}$ & $18.5 \mathrm{a}$ & $18.6 \mathrm{a}$ & $19.9 b$ & $17.8 \mathrm{ac}$ & $17.0 \mathrm{c}$ & $17.7 \mathrm{ac}$ & $17.7 \mathrm{ac}$ \\
\hline Glu & $96.0 \mathrm{a}$ & $98.4 \mathrm{a}$ & $99.6 \mathrm{ab}$ & $103.6 \mathrm{~b}$ & $88.3 c$ & $86.5 c$ & $92.2 \mathrm{~d}$ & $91.4 \mathrm{~d}$ \\
\hline Gly & $11.2 \mathrm{ac}$ & $11.4 \mathrm{ac}$ & $11.6 \mathrm{ac}$ & $12.4 \mathrm{~b}$ & $10.8 \mathrm{c}$ & $10.4 \mathrm{c}$ & $10.8 \mathrm{c}$ & $10.6 \mathrm{c}$ \\
\hline His & $10.5 \mathrm{a}$ & $10.5 \mathrm{a}$ & $10.6 \mathrm{a}$ & $11.3 \mathrm{a}$ & $10.8 \mathrm{a}$ & $10.2 \mathrm{a}$ & $10.7 \mathrm{a}$ & $10.2 \mathrm{a}$ \\
\hline Leu & $2.9 \mathrm{a}$ & $3.0 \mathrm{a}$ & $3.1 \mathrm{a}$ & $3.3 \mathrm{a}$ & $2.9 \mathrm{a}$ & $2.8 \mathrm{a}$ & $2.9 \mathrm{a}$ & $2.9 a$ \\
\hline Lys & $7.7 \mathrm{a}$ & $7.8 \mathrm{a}$ & $7.9 a$ & $8.5 a$ & $7.4 \mathrm{a}$ & $7.0 \mathrm{a}$ & $7.5 a$ & $7.3 a$ \\
\hline Ile & $2.0 \mathrm{a}$ & $2.0 \mathrm{a}$ & $2.1 \mathrm{a}$ & $2.2 \mathrm{a}$ & $1.9 \mathrm{a}$ & $1.8 \mathrm{a}$ & $1.9 \mathrm{a}$ & $1.9 \mathrm{a}$ \\
\hline Met & $0.6 a$ & $0.6 a$ & $0.6 \mathrm{a}$ & $0.7 \mathrm{a}$ & $0.6 \mathrm{a}$ & $0.6 a$ & $0.6 a$ & $0.6 a$ \\
\hline Phe & $1.5 a$ & $1.5 a$ & $1.6 a$ & $1.7 \mathrm{a}$ & $1.4 \mathrm{a}$ & $1.3 a$ & $1.4 \mathrm{a}$ & $1.4 \mathrm{a}$ \\
\hline Pro & $4.6 \mathrm{a}$ & $4.6 \mathrm{a}$ & $4.7 \mathrm{a}$ & $4.8 \mathrm{a}$ & $4.3 a$ & $4.2 \mathrm{a}$ & $4.4 \mathrm{a}$ & $4.3 \mathrm{a}$ \\
\hline Ser & $12.7 \mathrm{a}$ & $13.2 \mathrm{a}$ & $13.6 \mathrm{ab}$ & $14.4 \mathrm{~b}$ & $12.3 \mathrm{ac}$ & $11.8 \mathrm{c}$ & 12.4ac & 12.1ac \\
\hline Thr & $12.5 \mathrm{ac}$ & $12.8 \mathrm{ac}$ & $13.1 \mathrm{ab}$ & $14.0 \mathrm{~b}$ & $12.2 \mathrm{a}$ & $11.9 \mathrm{c}$ & $12.3 c$ & $12.3 \mathrm{c}$ \\
\hline Tyr & $1.8 \mathrm{a}$ & $1.8 \mathrm{a}$ & $1.8 \mathrm{a}$ & $1.9 \mathrm{a}$ & $1.7 \mathrm{a}$ & $1.7 \mathrm{a}$ & $1.8 \mathrm{a}$ & $1.7 \mathrm{a}$ \\
\hline Val & $3.7 \mathrm{a}$ & $3.8 \mathrm{a}$ & $3.9 a$ & $4.2 \mathrm{a}$ & $3.6 \mathrm{a}$ & $3.4 \mathrm{a}$ & $3.5 \mathrm{a}$ & $3.5 \mathrm{a}$ \\
\hline Total & $352.9 \mathrm{a}$ & $358.6 \mathrm{a}$ & $363.1 \mathrm{ab}$ & $377.6 \mathrm{~b}$ & $344.9 \mathrm{ac}$ & $335.1 \mathrm{c}$ & $357.3 a$ & 348.1ac \\
\hline
\end{tabular}

Control (without starter culture).

Results are expressed as means of three replicates in $\mathrm{mmol} / \mathrm{g}$ dry matter.

Means with different letters along rows are significantly different $(P<0.05)$.

Table 3. Amino acid content of Nham without and with starter cultures during stored at $4^{\circ} \mathrm{C}$.

\begin{tabular}{|c|c|c|c|c|c|c|c|c|}
\hline \multirow{2}{*}{$\begin{array}{c}\text { Amino } \\
\text { acid }\end{array}$} & \multicolumn{4}{|c|}{ Control } & \multicolumn{4}{c|}{ L. plantarum + L. sake } \\
\cline { 2 - 9 } & \multicolumn{4}{|c|}{ Storage time (wk) } & \multicolumn{4}{c|}{ Storage time (wk) } \\
\cline { 2 - 9 } & 1 & 2 & 3 & 4 & 1 & 2 & 3 & 4 \\
\hline Ala & $20.3 \mathrm{a}$ & $21.7 \mathrm{ad}$ & $31.2 \mathrm{~b}$ & $37.9 \mathrm{c}$ & $23.0 \mathrm{~d}$ & $23.1 \mathrm{~d}$ & $27.3 \mathrm{e}$ & $31.8 \mathrm{~b}$ \\
\hline Arg & $147.5 \mathrm{a}$ & $159.4 \mathrm{~b}$ & $237.5 \mathrm{c}$ & $288.0 \mathrm{~d}$ & $155.9 \mathrm{~b}$ & $162.4 \mathrm{~b}$ & $191.7 \mathrm{e}$ & $231.4 \mathrm{c}$ \\
\hline Asp & $3.2 \mathrm{a}$ & $3.3 \mathrm{a}$ & $5.0 \mathrm{~b}$ & $6.3 \mathrm{c}$ & $3.1 \mathrm{a}$ & $3.2 \mathrm{a}$ & $3.9 \mathrm{a}$ & $4.8 \mathrm{~b}$ \\
\hline Cys & $18.5 \mathrm{a}$ & $19.5 \mathrm{a}$ & $28.5 \mathrm{~b}$ & $36.1 \mathrm{c}$ & $18.6 \mathrm{a}$ & $19.0 \mathrm{a}$ & $23.4 \mathrm{~d}$ & $27.8 \mathrm{~b}$ \\
\hline Glu & $91.6 \mathrm{a}$ & $97.3 \mathrm{~b}$ & $146.3 \mathrm{c}$ & $183.7 \mathrm{~d}$ & $91.1 \mathrm{a}$ & $93.2 \mathrm{a}$ & $114.0 \mathrm{e}$ & $138.8 \mathrm{f}$ \\
\hline Gly & $11.0 \mathrm{a}$ & $11.5 \mathrm{a}$ & $16.9 \mathrm{~b}$ & $21.1 \mathrm{c}$ & $11.1 \mathrm{a}$ & $11.5 \mathrm{a}$ & $14.1 \mathrm{~d}$ & $16.8 \mathrm{~b}$ \\
\hline
\end{tabular}




\begin{tabular}{|c|c|c|c|c|c|c|c|c|}
\hline His & $10.4 \mathrm{a}$ & $11.2 \mathrm{a}$ & $16.2 \mathrm{~b}$ & $20.5 \mathrm{c}$ & $11.3 \mathrm{a}$ & $11.4 \mathrm{a}$ & $13.8 \mathrm{~d}$ & $16.0 \mathrm{~b}$ \\
\hline Leu & $3.1 \mathrm{a}$ & $3.3 \mathrm{a}$ & $4.9 \mathrm{~b}$ & $6.0 \mathrm{c}$ & $3.1 \mathrm{a}$ & $3.2 \mathrm{a}$ & $3.9 \mathrm{a}$ & $4.6 \mathrm{~b}$ \\
\hline Lys & $7.1 \mathrm{a}$ & $7.5 \mathrm{a}$ & $11.3 \mathrm{~b}$ & $13.9 \mathrm{c}$ & $7.5 \mathrm{a}$ & $7.8 \mathrm{a}$ & $9.2 \mathrm{~d}$ & $10.9 \mathrm{e}$ \\
\hline Ile & $1.9 \mathrm{a}$ & $2.1 \mathrm{a}$ & $3.1 \mathrm{ab}$ & $3.8 \mathrm{~b}$ & $1.9 \mathrm{a}$ & $2.0 \mathrm{a}$ & $2.5 \mathrm{a}$ & $3.0 \mathrm{ab}$ \\
\hline Met & $0.6 \mathrm{a}$ & $0.6 \mathrm{a}$ & $0.9 \mathrm{a}$ & $1.2 \mathrm{a}$ & $0.6 \mathrm{a}$ & $0.6 \mathrm{a}$ & $0.8 \mathrm{a}$ & $0.9 \mathrm{a}$ \\
\hline Phe & $1.4 \mathrm{a}$ & $1.5 \mathrm{a}$ & $2.3 \mathrm{ab}$ & $2.9 \mathrm{~b}$ & $1.5 \mathrm{a}$ & $1.5 \mathrm{a}$ & $1.8 \mathrm{a}$ & $2.2 \mathrm{ab}$ \\
\hline Pro & $4.3 \mathrm{a}$ & $4.5 \mathrm{a}$ & $6.7 \mathrm{~b}$ & $8.3 \mathrm{c}$ & $4.3 \mathrm{a}$ & $4.6 \mathrm{a}$ & $5.6 \mathrm{a}$ & $6.7 \mathrm{~b}$ \\
\hline Ser & $12.8 \mathrm{a}$ & $13.9 \mathrm{a}$ & $20.7 \mathrm{~b}$ & $26.2 \mathrm{c}$ & $13.0 \mathrm{a}$ & $13.1 \mathrm{a}$ & $15.8 \mathrm{~d}$ & $19.3 \mathrm{~b}$ \\
\hline Thr & $11.7 \mathrm{a}$ & $12.5 \mathrm{a}$ & $18.7 \mathrm{~b}$ & $23.1 \mathrm{c}$ & $12.7 \mathrm{a}$ & $12.8 \mathrm{a}$ & $15.4 \mathrm{~d}$ & $18.4 \mathrm{~b}$ \\
\hline Tyr & $1.8 \mathrm{a}$ & $1.9 \mathrm{a}$ & $2.7 \mathrm{~b}$ & $3.4 \mathrm{c}$ & $1.8 \mathrm{a}$ & $1.9 \mathrm{a}$ & $2.3 \mathrm{ab}$ & $2.7 \mathrm{~b}$ \\
\hline Val & $3.7 \mathrm{a}$ & $3.9 \mathrm{a}$ & $5.9 \mathrm{~b}$ & $7.5 \mathrm{c}$ & $3.8 \mathrm{a}$ & $3.8 \mathrm{a}$ & $4.6 \mathrm{a}$ & $5.5 \mathrm{~b}$ \\
\hline Total & $348.8 \mathrm{a}$ & $367.2 \mathrm{a}$ & $542.4 \mathrm{~b}$ & $657.7 \mathrm{c}$ & $359.1 \mathrm{a}$ & $374.0 \mathrm{a}$ & $461.2 \mathrm{~d}$ & $547.1 \mathrm{e}$ \\
\hline
\end{tabular}

Control (without starter culture).

Results are expressed as means of three replicates in mmol/g dry matter.

Means with different letters along rows are significantly different $(P<0.05)$.

Table 4. Amino acid content of Nham without and with starter cultures during stored at $15^{\circ} \mathrm{C}$.

\begin{tabular}{|c|c|c|c|c|c|c|c|c|}
\hline \multirow{3}{*}{$\begin{array}{l}\text { Amin } \\
\text { o } \\
\text { acid }\end{array}$} & \multicolumn{4}{|c|}{ Control } & \multicolumn{4}{|c|}{ L. plantarum + L. sake } \\
\hline & \multicolumn{4}{|c|}{ Storage time (wk) } & \multicolumn{4}{|c|}{ Storage time (wk) } \\
\hline & 1 & 2 & 3 & 4 & 1 & 2 & 3 & 4 \\
\hline Ala & $35.6 a$ & $40.6 b$ & $103.8 \mathrm{c}$ & $122.6 \mathrm{~d}$ & $31.5 \mathrm{e}$ & $41.8 \mathrm{~b}$ & $68.2 \mathrm{f}$ & $76.2 \mathrm{~g}$ \\
\hline Arg & $232.9 a$ & $280.6 b$ & $710.9 \mathrm{c}$ & $832.7 \mathrm{~d}$ & $212.3 \mathrm{e}$ & $291.3 \mathrm{f}$ & $475.2 \mathrm{~g}$ & $531.2 \mathrm{~h}$ \\
\hline Asp & $4.7 \mathrm{a}$ & $5.8 \mathrm{ad}$ & $14.7 \mathrm{~b}$ & $17.1 \mathrm{c}$ & $4.1 \mathrm{a}$ & $5.6 \mathrm{~d}$ & $9.5 \mathrm{e}$ & $11.0 \mathrm{f}$ \\
\hline Cys & $28.7 \mathrm{a}$ & $34.6 \mathrm{~b}$ & $86.9 \mathrm{c}$ & $101.8 \mathrm{~d}$ & $24.0 \mathrm{a}$ & $32.3 b$ & $55.1 \mathrm{e}$ & $64.4 \mathrm{f}$ \\
\hline Glu & $140.9 a$ & $174.2 \mathrm{~b}$ & $433.8 \mathrm{c}$ & $512.6 \mathrm{~d}$ & $118.7 \mathrm{e}$ & $160.1 \mathrm{f}$ & $270.5 \mathrm{~g}$ & $313.2 \mathrm{~h}$ \\
\hline Gly & $16.9 \mathrm{a}$ & $20.3 b$ & $50.6 \mathrm{c}$ & $59.2 d$ & $14.2 \mathrm{e}$ & $19.3 b$ & $32.9 \mathrm{f}$ & $37.8 \mathrm{~g}$ \\
\hline His & $17.8 \mathrm{a}$ & $21.0 \mathrm{~b}$ & $52.8 \mathrm{c}$ & $62.4 \mathrm{~d}$ & $15.1 \mathrm{a}$ & $20.4 b$ & $34.1 \mathrm{e}$ & $39.5 \mathrm{f}$ \\
\hline Leu & $4.8 \mathrm{a}$ & $5.9 \mathrm{a}$ & $14.6 \mathrm{~b}$ & $17.0 \mathrm{c}$ & $4.1 \mathrm{a}$ & $5.6 a$ & $9.4 \mathrm{~d}$ & $10.9 \mathrm{e}$ \\
\hline Lys & $10.9 a$ & $13.5 b$ & $34.6 c$ & $39.8 d$ & $9.9 \mathrm{a}$ & $13.3 b$ & $21.8 \mathrm{e}$ & $25.0 \mathrm{f}$ \\
\hline Ile & $3.0 \mathrm{a}$ & $3.6 a$ & $8.9 \mathrm{~b}$ & $10.1 \mathrm{c}$ & $2.6 a$ & $3.4 \mathrm{a}$ & $5.9 \mathrm{~d}$ & $6.7 \mathrm{~d}$ \\
\hline Met & $0.9 a$ & 1.1ad & $2.8 \mathrm{bc}$ & $3.2 \mathrm{c}$ & $0.8 \mathrm{a}$ & $1.1 \mathrm{ad}$ & $1.9 \mathrm{~d}$ & $2.1 \mathrm{~d}$ \\
\hline Phe & $2.3 \mathrm{ac}$ & $2.8 \mathrm{a}$ & $7.1 \mathrm{~b}$ & $8.2 b$ & $1.9 \mathrm{c}$ & $2.6 a$ & $4.4 \mathrm{~d}$ & $5.1 \mathrm{~d}$ \\
\hline Pro & $6.5 a$ & $8.0 \mathrm{~b}$ & $20.5 c$ & $23.6 \mathrm{~d}$ & $5.9 a$ & $7.9 \mathrm{~b}$ & $13.5 \mathrm{e}$ & $15.0 \mathrm{f}$ \\
\hline Ser & $20.1 \mathrm{a}$ & $24.2 b$ & $60.3 c$ & $68.2 d$ & $16.8 \mathrm{e}$ & $22.8 \mathrm{e}$ & $38.3 \mathrm{f}$ & $44.7 \mathrm{~g}$ \\
\hline Thr & $17.7 \mathrm{a}$ & $21.9 b$ & $56.0 \mathrm{c}$ & $66.2 d$ & $16.4 \mathrm{a}$ & $22.2 b$ & $36.8 \mathrm{e}$ & $41.2 \mathrm{f}$ \\
\hline Tyr & $2.8 \mathrm{a}$ & $3.4 \mathrm{a}$ & $8.4 \mathrm{~b}$ & $9.8 \mathrm{c}$ & $2.4 \mathrm{a}$ & $3.2 \mathrm{a}$ & $5.5 \mathrm{~d}$ & $6.4 \mathrm{~d}$ \\
\hline Val & $5.7 \mathrm{a}$ & $7.0 \mathrm{~b}$ & $17.8 \mathrm{c}$ & $21.0 \mathrm{~d}$ & $5.0 \mathrm{a}$ & $6.6 \mathrm{~b}$ & $10.9 \mathrm{e}$ & $12.7 \mathrm{f}$ \\
\hline Total & $541.0 \mathrm{a}$ & $651.8 \mathrm{~b}$ & $1637.2 \mathrm{c}$ & $1851.7 \mathrm{~d}$ & $472.0 \mathrm{e}$ & $647.8 \mathrm{~b}$ & $1103.9 \mathrm{f}$ & $1256.0 \mathrm{~g}$ \\
\hline
\end{tabular}

Control (without starter culture).

Results are expressed as means of three replicates in mmol/g dry matter.

Means with different letters along rows are significantly different $(P<0.05)$.

Table 5. Amino acid content of Nham without and with starter cultures during stored at $25^{\circ} \mathrm{C}$. 
Two types of fermented sausage differing in starter culture were produced in parallel with two different starter cultures (no starter and L. plantarum + L. sake). The sausages were ripened 3 days and subsequently stored $7,14,21$ and 28 days at the $4{ }^{\circ} \mathrm{C}, 15^{\circ} \mathrm{C}$ and $25^{\circ} \mathrm{C}$. Concentration of three most abundant amines, cadaverine, putrescine and tyramine increased significantly $(P<0.05)$ in Nham during ripening and and also during storage. The dominant BAs in the control were cadaverine - and tyramine and putrescine, to a lesser extent; the cadaverine, putrescine and tyramine content were lower if inoculation had added with L. plantarum + L. sake; whereas they ranked above $300 \mathrm{mg} / \mathrm{kg}$ in the control by $3 \mathrm{~d}$. At the end of ripening, cadaverine $(98.7 \mathrm{mg} / \mathrm{kg}$ dry matter), putrescine $(242.6 \mathrm{mg} / \mathrm{kg}$ dry matter) and tyramine $(46.4 \mathrm{mg} / \mathrm{kg}$ dry matter) content in the A-samples-sausage was higher $(P<0.05)$ than in Nham with starters $(51.6,98.4$ and $27.8 \mathrm{mg} / \mathrm{kg}$ dry matter, respectively). Starter culture influenced significantly in decrease of $(P<0.05)$ cadaverine, putrescine and tyramine content in the sausage. Due to the significant $(P<0.05)$ increase of total aerobic counts in the Nham control between the end of ripening and during storage, followed by the significant $(P<0.05)$ increase of the sum of total BAs between the 72 hour of ripening (387.7 $\mathrm{mg} / \mathrm{kg}$ dry matter $)$ and the $4^{\text {th }}$ week of storage at $25^{\circ} \mathrm{C}(629.2 \mathrm{mg} / \mathrm{kg}$ dry matter $)$.

The main rate of BAs production was during the first two days, when a sharp $\mathrm{pH}$ decrease and the development of LAB occurred. Sausages fermented with starters had lower amounts of cadaverine, putrescine and tyramine than naturally fermented sausages (control) during storage at $15^{\circ} \mathrm{C}$ and $25^{\circ} \mathrm{C}$. However, phenylethylamine, histamine and tryptamine were not detected.

Nham control showed proteolysis that was correlated with $\mathrm{pH}$ values higher than those with starters. However, no positive correlation was found between the proteolysis index and BAs production. Since proteolysis was stronger during the second half of the ripening process, the FAAs occurred later than the early amine production. No effect on $\mathrm{pH}$ development in the fermented sausage was observed when non-amine forming strain of $L$. plantarum $+L$. sake were present during 4 week of $4^{\circ} \mathrm{C}$ storage period. A study on the evolution of FAAs and BAs in Nham during 4 week at different temperatures of storage $\left(4^{\circ} \mathrm{C}, 15^{\circ} \mathrm{C}\right.$ and $\left.25^{\circ} \mathrm{C}\right)$ was performed. FAAs and BAs were determined by RP-HPLC. Storage temperature of $15^{\circ} \mathrm{C}$ and $25^{\circ} \mathrm{C}$ promoted a significant increase of the contents of arginine, glutamic acid, cadaverine, putrescine and tyramine, expressed as $\mathrm{g} / \mathrm{kg}$ of dry matter while storage temperature of $4^{\circ} \mathrm{C}$ decreased a significant of the contents of arginine, glutamic acid, cadaverine, putrescine and tyramine, expressed as $\mathrm{g} / \mathrm{kg}$ of dry matter. These two amino acids and three BAs may serve as indicators of temperatures changes in stored fermented sausage.

\section{Conclusions}

The aim of this study was to investigate the effect of non-amine forming LAB as starter culture during ripening and storage time and temperature on the evolution of FAAs of Nham during processing. The correlation between FAAs and BAs content was also investigated. Larger increases of FAAs occurred in Nham without starter in the ripening and storage step. Total FAAs content was highly correlated with total BAs amount. Sausage 
ripening was further carried out with non-amine forming strain of L. plantarum + L. sake after ripening and stored at different temperature. The amount of amine in the product was significantly less than the control. The results obtained for BAs degradation by bacteria in a synthetic medium suggest that $\mathrm{AO}$ activity is strain dependent rather than being related to specific species. In all batchs, the total amino acid contents increased with time - and the predominant ones were arginine and glutamic acid. However, upon inoculation with nonamine forming strain, the total BAs contents remained considerably lower than those of the control. Hence, an efficient food-grade biological tool was made available that constrains buildup of BAs in fermented sausage during storage.

\section{Author details}

Jirasak Kongkiattikajorn

School of Bioresources and Technology, King Mongkut's University of Technology Thonburi, Thailand

\section{Acknowledgement}

This study was supported by Office of the Higher Education Commission (OHEC), Thailand.

\section{References}

AOAC. (2000). Official methods of analysis (17th ed.). Gaithersburg, Maryland: Association of Official Analytical Chemists.

Benjakul, S., \& Morrissey, M. T. (1997). Protein hydrolysates from Pacific whiting solid wastes. Journal of Agricultural and Food Chemistry, Vol.45, pp. 3423-3430.

Beutling, D. (1996). Biogenic Amines in Nutrition (Biogene Amine in der Ernaehrung). Springer-Verlag, Berlin, Germany, pp. 59-67.

Bover-Cid, S., Hugas, M., Izquierdo-Pulido, M. \& Vidal-Carou, M.C. (2000). Reduction of biogenic amine formation using a negative amino acid-decarboxylase starter culture for ripening of fuet sausage. Journal of Food Protection, Vol. 63, No.2, pp. 237-243.

Bover-Cid, S., Izquierdo-Pulido, M. \& Vidal-Carou, M. C. (2000). Influence of hygienic quality of raw materials on biogenic amine production during ripening and storage of dry fermented sausage. Journal of Food Protection, Vol. 63, pp. 1544-1550.

Bover-Cid, S., Hugas, M., Izquierdo-Pulido, M. \& Vidal-Carou, M. C. (2001). Amino aciddecarboxylase activity of bacteria isolated from fermented pork sausages. International Journal of Food Microbiology, Vol. 66, pp. 185-189.

Bolumar, T., Nieto, P. \& Flores, J. (2001). Acidity, proteolysis and lipolysis changes in rapid cured fermented sausage dried at different temperatures. Food Science and Technology International, Vol.7, pp. 269-276.

Brink, B. ten., Damink, C., Joosten, H. M. L. J. \& Huis in't Veld, J. H. J. (1990). Occurrence and formation of biologically active amines in foods. International Journal of Food Microbiology, Vol.11, pp. 73-84.

Bruna, J. M., Fernandez, M., Hierro, E. M., Ordonez, J. A. \& De la Hoz, L. (2000). Combined use of pronase $\mathrm{E}$ and a fungal extract (Penicillium aurantiogriseum) to potentiate the sensory characteristics of dry fermented sausages. Meat Science, Vol.54, pp. 135-145. 
Buscailhon, S., Berdagué, J. L., Bousset, J., Gandemer, G., Cornet, M. \& Touraille, C. (1994). Relations between compositional traits and sensory qualities of French dry-cured ham. Meat Science, Vol.37, pp. 229-243.

Cooper, R.A., 1997. On the amine oxidases of Klebsiella aerogenes strain W70. FEMS Microbiology Letters 146, 85- 89.

Hernández-Jover, T., Izquierdo-Pulido, M.,Veciana-Nogués, M.T. \& Vidal-Carou, M.C. (1996). Ion-pair high-performance liquid chromatographic determination of biogenic amines in meat and meat products. Journal of Agricultural and Food Chemistry, Vol. 44, No.9, pp. 2710-2715.

De Masi, T. W., Wardlaw, F. B., Dick, R. L. \& Acton, J. C. (1990). Non protein nitrogen (NPN) and free amino acid contents of dry fermented and non fermented sausages. Meat Science, Vol.27, pp. 1-12.

Durà, M. A., Flores, M. \& Tolrà, F. (2004). Effect of Debaryomyces spp. On the proteolysis of dry-fermented sausages. Meat Science, Vol.68, pp. 319-328.

Dapkevicius, M.L.N.E., Nout, M.J.R., Rombouts, F.M., Houben, J.H. \& Wymenga, W., 2000. Biogenic amine formation and degradation by potential fish silage starter microorganisms. International Journal of Food Microbiology, Vol.57, pp. 107- 114.

Eerola, S., Roig-Saguèz, A. X. \& Hirvi, T. K. (1998). Biogenic amines in Finnish dry sausages. Journal of Food Safety, Vol.18, pp. 127-138.

Flores, M., Spanier, A. M. \& Toldrá, F. (1998). Flavour analysis of dry-cured ham. In Shahidi, F. (Ed.), Flavour of meat product and seafood pp. 320-341. London: Blackie.

Gale, E. F. (1946). The bacterial amino acid decarboxylases. In Nord, F. F. (Ed.), Advances in enzymology, Vol. 6, New York: Interscience Publisher.

Gardini, F., Martuscelli, M., Caruso, M. C., Galgano, F., Crudele, M. A. \& Favati, F. (2001). Effects of $\mathrm{pH}$, temperature and $\mathrm{NaCl}$ concentration on the growth kinetics, proteolytic activity and biogenic amine production of Enterococcus faecali. International Journal of Food Microbiology, Vol.64, pp. 105-117.

Gardini, F., Martuscelli, M., Crudele, M.A., Paparella, A. \& Suzzi, G., 2002. Use of Staphylococcus xylosus as a starter culture in dried sausages: effect on the biogenic amine content. Meat Science, Vol. 61, pp. 275- 281.

Greene, D. H., \& Babbitt, J. K. (1990). Control of muscle softening and protease-parasite interactions in arrowtooth flounder, Ateresthes stomias. Journal of Food Science, Vol.55, pp. 579-580.

Hierro, E., De la Hoz, L. \& Ordonez, J. A. (1999). Contribution of the microbial and meat endogenous enzymes to the free amino acid and amine contents of dry fermented sausages. Journal of Agriculture and Food Chemistry, Vol.47, pp. 1156-1161.

Hughes, M. C., Kerry, J. P., Arendt, E. K., Kenneally, P. M., McSweeney, P. L. H. \& O'Neill, E. E. (2002). Characterization of proteolysis during the ripening of semidry fermented sausages. Meat Science, Vol.62, pp. 205-216.

Ishizuka, H., Horinouchi, S. \& Beppu, T., 1993. Putrescine oxidase of Micrococcus rubens: primary structure and Escherichia coli. General Microbiology, Vol.139, pp. 425-432.

Joosten, H.M.L.J. \& Northolt, M.D. (1989). Detection, growth and amine producing capacity of lactobacilli in cheese. Applied and Environmental Microbiology, Vol. 55, No.9, pp. 23562359. 
Kalac, P., Spicka, J., Krizek, M. and Pelikanova, T. (2000). The effect of lactic acid bacteria inoculants on biogenic amines formation in sauerkraut. Food Chemistry, Vol.70, pp. 355359.

Lehane, L. \& Olley, J., 2000. Histamine fish poisoning revisited. International Journal of Food Microbiology, Vol.58, pp. $1-37$.

Lehninger, A. L., Nelson, D. L. \& Cox, M. M. (1999). Principi di biochimica, ed. Zanichelli, Bologna.

Leuschner, R.G.K. \& Hammes, W.P., 1998. Tyramine degradation by micrococci during ripening of fermented sausages. Meat Science, Vol.49, pp. 289-296.

Lowry, Q. H., Rosebrough, N. J., Farr, L. A., \& Randall, R. J. (1951). Protein measurement with the Folin phenol reagent. Journal of Biological Chemistry, Vol.193, pp. 256-275.

Mah, J.H. \& Hwang, H.J. (2009). Inhibition of biogenic amine formation in a salted and fermented anchovy by Staphylococcus xylosus as a protective culture. Food Control, Vol. 20, pp. 796-801.

Maijala, R. (1994). Histamine and tyramine production by a Lactobacillus strain subjected to external pH decrease. Journal of Food Protection, Vol.57, pp. 259-262.

Maijala, R., Eerola, S., Lievonen, S., Hill, P. \& Hirvi, T. (1995). Formation of biogenic amines during ripening of dry sausages as affected by starter culture and thawing time of raw materials. Journal of Food Science, Vol.60, pp. 1187-1190.

Martuscelli, M., Crudele, M.A., Gardini, F. \& Suzzi, G., 2000. Biogenic amine formation and oxidation by Staphylococcus xylosus strains from artisanal fermented sausages. Letters in Applied Microbiology, Vol.31, pp. 228- 232.

Molina, I. \& Toldrà, F. (1992). Detection of proteolytic activity in microorganisms isolated from dry-cured ham. Journal of Food Science, Vol. 57, pp. 1308-1310.

Montel, M. C. \& Champomier, M. C. (1987). Arginine catabolism in Lactobacillus sake from meat. Applied and Environmental Microbiology, Vol.53, pp. 2683-2685.

Molly, K., Demeyer, D., Johansson, G., Raemaekers, M., Ghistelinck, M. \& Geenen, I. (1997). The importance of meat enzymes in ripening and flavour generation in dry fermented sausages. First results of a European project. Food Chemistry, Vol.59, pp. 539-545.

Monin, G., Marinova, P., Talmant, A., Martin, J. F., Cornet, M. \& Lanore, D. (1997). Chemical and structural changes in dry-cured hams (Bayonne hams) during processing and effects of the deharing technique. Meat Science, Vol.47, pp. 29-47.

Montel, M. C. \& Champomier, M. C. (1987). Arginine catabolism in Lactobacillus sake from meat. Applied and Environmental Microbiology, Vol.53, pp. 2683-2685.

Moreno-Arribas, M. V., Polo, M. C., Jorganes, F., \& Munoz, R. (2003). Screening of biogenic amine production by acid lactic bacteria isolated from grape must and wine. International Journal of food Microbiology, Vol.84, pp. 117-123.

Murooka, Y., Doi, N. \& Harada, T., 1979. Distribution of membrane bound monoamine oxidase in bacteria. Applied and Environmental Microbiology, Vol.38, pp. 565- 569.

Murooka, Y., Higashiura, T. \& Harada, T., 1976. Regulation of tyramine oxidase synthesis in Klebsiella aerogenes. Journal of Bacteriology, Vol.127, pp. 24-31.

Ordonez, J. A., Hierro, E. M., Bruna, J. M. \& De la Hoz, L. (1999). Changes in the components of dry-fermented sausages during ripening. Critical Reviews in Food Science and Nutrition, Vol.39, pp. 329-367. 
Rodrìguez, M., Núňez, J. J., Cródoba, M. E., Bermúdez, M. E. \& Asensio, M. A. (1998). Evolution of proteolytic activity of micro-organisms isolated from dry-cured ham. Journal of Applied Microbiology, Vol.85, pp. 905-912.

Rozan, P., Kuo, Y.H. \& Lambein, F. (2000). Free amino acids present in commercially available seedlings sold for human consumption: a potential hazard for consumers. Journal of Agricultural and Food Chemistry, Vol. 48, No.3, pp. 716-723.

Ruiz, J., Garcia, C., Diaz, M. C., Cava, R., Tejeda, F. J. \& Ventanas, J. (1999). Dry cured Iberian ham non-volatile components as affected by the length of the curing process. Food Research International, Vol.32, pp. 643-651.

Ruiz-Capillas, C. \& Moral, A. (2001). Production of biogenic amines and their potential use as quality control index foer hake (Merluccius merluccius L.) stored in ice. Journal of Food Science, Vol.66, pp. 1030-1032.

Scannell, A. G. M., Kenneally, P. M. \& Arendt, E. K. (2004). Contribution of starter cultures to the proteolytic process of a fermented non-dried whole muscle ham product. International Journal of Food Microbiology, Vol.93, pp. 219-230.

Schomburg, D. \& Stephan, D., 1993. Enzyme Handbook. Springer-Verlag, Berlin, Germany.

Sekikawa, M., Kawamura, T., Fujii, H., Shimada, K., Fukushima, M. \& Mikami, M.(2003). Effect of arginine on growth of lactic acid bacteria for fermented sausage under high concentration of salt. Hokkaido Animal Science and Agriculture Society, Vol.45, pp. 17-23.

Silla-Santos, M. H. (1996). Biogenic amines: Their importance in food. International Journal of Food Microbiology, 29, pp. 213-221.

Suzzi, G. \& Gardini, F. (2003). Biogenic amines in dry fermented sausages: A review. International Journal of Food Microbiology, Vol.88, pp. 41-54.

Toldrá, F. (2005). Dry-cured ham. In Hui, Y. H., Culbertson, J. D., Duncan, S., GuerreroLegarreta, I., Li-Chan, E. C. Y., Ma, C. Y., Manley, C. H., McMeekin, T. A., Nip, W. K., Nollet, L. M. L., Rahman, M. S., Toldrá, F., \&. Xiong, Y. L (Eds.). Handbook of food science, technology and engineering (Vol. 1). Boca Raton, FL: USA, Marcel-Dekker Inc./CRC Press.

Toldrá, F. (2006). The role of muscle enzymes in dry-cured meat products with different drying conditions. Trends in Food Science and Technology, Vol.17, pp. 164-168

Ventanas, J., Cordoba, J. J., Antequera, T., Garcìa, C., López-Bote, C. \& Asensio, M. A. (1992). Hydrolysis and Maillard reactions during ripening of Iberian ham. Journal of Food Science, Vol.57, No.4, pp. 813-815.

Verges, C.M.C., Zuniga, M., Morel-Deville, F., Perez-Martinez, G., Zagorec, M. \& Ehrlich, S.D. (1999). Relationships between arginine degradation, $\mathrm{pH}$ and survival in Lactobacillus sake. FEMS Microbiology Letter, Vol. 180, pp. 297-304.

Verplaetse, A., De Bosschere, M. \& Demeyer, D. (1989). Proteolysis during dry sausage ripening. In Proceedings of the $35^{\text {th }}$ international congress on meat science and technology. Copenhaegen, Denmark.

Virgili, R., Saccani, G., Gabba, L., Tanzi, E. \& Soresi Bordini, C. (2007). Changes of free amino acids and biogenic amines during estende ageing of Italian dry-cured ham. LWT - Food Science and Technology, Vol.40, No.5, pp. 871-878.

Yamashita, M., Sakaue, M., Iwata, M., Sugino, H. \& Murooka, Y. (1993). Purification and characterization of monoamine oxidase from Klebsiella aerogenes. Journal of Ripening and Bioengineering, Vol. 76, pp. 289-295. 